\title{
The Mineral Dust Cycle in EMAC 2.40: sensitivity to the spectral resolution and the dust emission scheme
}

\author{
G. Gläser ${ }^{1}$, A. Kerkweg ${ }^{1}$, and H. Wernli ${ }^{2}$ \\ ${ }^{1}$ Institute for Atmospheric Physics, University of Mainz, 55099 Mainz, Germany \\ ${ }^{2}$ Institute for Atmospheric and Climate Science, ETH Zurich, Zurich, Switzerland \\ Correspondence to: G. Gläser (glaeseg@uni-mainz.de)
}

Received: 22 June 2011 - Published in Atmos. Chem. Phys. Discuss.: 5 October 2011

Revised: 16 January 2012 - Accepted: 6 February 2012 - Published: 14 February 2012

\begin{abstract}
This first detailed analysis of the mineral dust cycle in the ECHAM5/MESSy Atmospheric Chemistry (EMAC) model system investigates the performance of two dust emission schemes, following the approach of Balkanski et al. (2004) and Tegen et al. (2002), respectively, and the influence of the horizontal model resolution. Here the spectral resolutions T42, T63, T85, and T106 are investigated. A basic sulphur chemistry, enabling the coating of insoluble dust particles to make them soluble, is employed in order to realistically describe the ageing and wet deposition of mineral dust. Independent of the dust emission scheme the fiveyear simulations with the horizontal resolutions T42 and T63 produce unrealistically high emissions at some grid points in the Tarim Basin in Central Asia, leading to very high dust loads in polar regions. With these coarse resolutions, dust source grid points in the basin and elevated grid points of the Himalayas with high wind speeds cannot be distinguished, causing this overestimation. In T85 and T106 these regions are well separated and considerably less dust is emitted there. With the chosen model setup, the dust emission scheme by Balkanski et al. (2004) places the global maximum of emissions in the Thar Desert in India. This is unrealistic as the Sahara Desert is known to be the largest dust source in the world. This is the main deficiency of this scheme compared to the one by Tegen et al. (2002), which, based on a qualitative comparison to AEROCOM data, produces a very reasonable distribution of emissions and dust loads in simulations with resolutions T85 and T106. For future climate simulations with EMAC focusing on mineral dust, we recommend to use the dust emission scheme by Tegen et al. (2002) and a model resolution of at least T85. Simulations of two selected episodes and comparison to observational data sets show that
\end{abstract}

in this model configuration EMAC is able to realistically simulate also intense, episodic events of dust emission and longrange transport.

\section{Introduction}

Airborne mineral dust particles have the potential to influence regional and global climate. Dust aerosol directly changes the radiation budget by scattering and absorption (Haywood et al., 2001; DeMott et al., 2003b). Dust particles also act very efficiently as ice nuclei (IN) causing indirect radiative effects by impacting ice clouds (Zuberi et al., 2002; DeMott et al., 2003a,b; Sassen et al., 2003). However, there are still huge uncertainties about the magnitude of these direct and indirect effects on the global climate (IPCC, 2007).

Furthermore, mineral dust influences oceans and rain forests by providing nutrients as iron and phosphorous to these ecosystems (Martin and Fitzwater, 1988; Swap et al., 1992; Chadwick et al., 1999). Moreover, dust particles can have negative impacts on human health (Kwon et al., 2002; Chen et al., 2004).

Due to uncertainties in the source and sink processes of the mineral dust cycle, Global Chemistry Climate Models (GCCMs) cover a very wide range of values for the global dust emission and deposition, the total dust burden and its atmospheric life time. In the AEROCOM project (http://nansen.ipsl.jussieu.fr/AEROCOM/) the results of several GCCMs have been compared with each other and with observations. Models simulate global dust emissions between 514 and $4313 \mathrm{Tg} \mathrm{yr}^{-1}$ and dust loads ranging from 6.8 to $29.5 \mathrm{Tg}$ (Textor et al., 2006; Huneeus et al., 2011). 
This study is the first detailed analysis and evaluation of the mineral dust cycle in the ECHAM5/MESSy Atmospheric Chemistry (EMAC) GCCM (http://www.messy-interface. org). It is known that Global Circulation Models (GCMs) can produce considerably different results depending on the model resolution. For instance, there are differences in the simulation of extratropical cyclones with the ECMWF model at various resolutions (Jung et al., 2006). Marti et al. (2010) reported resolution sensitivity of storm-tracks, characteristics of the NAO and inter-annual variability in the tropics with the "Institut Pierre Simon Laplace (IPSL) coupled oceanatmosphere GCM" and Bian et al. (2009) found resolution effects in the simulation of relative humidity and aerosol optical thickness with the GMI CTM. Therefore, we investigate the impact of the horizontal resolution on the dust cycle. For this, five-year time slice simulations with four different resolutions $\left(\mathrm{T} 42 \approx 2.8^{\circ}, \mathrm{T} 63 \approx 1.9^{\circ}, \mathrm{T} 85 \approx 1.4^{\circ}\right.$, and $\mathrm{T} 106 \approx 1.1^{\circ}$ ) are considered in this study. The time slices are driven by constant boundary conditions, e.g., monthly values of the sea surface temperature and the emissions of chemical species, to enable the calculation of climatological means.

We also analyse the impact of the dust emission scheme because this plays a decisive role for the simulation of the entire dust cycle (Kang et al., 2011). For each of the four model resolutions, simulations with two different emission schemes are conducted, namely, the schemes described in Balkanski et al. (2004) and in Tegen et al. (2002).

In addition to the climatological analyses the ability of EMAC to reproduce single dust outbreaks is studied. With the most reasonable model setup, in terms of reproducing the main climatological aspects, two episodes are simulated and compared with observational data sets. The first episode in May and June 2006 coincides with the SAMUM field campaign in southern Morocco (Kandler et al., 2009). The second episode covers a dust outbreak from the Sahara to Central Europe in May and June 2008. This dust plume is apparent in measurements of the IN concentration at Mt. Kleiner Feldberg in Germany (Klein et al., 2010).

In Sect. 2 we describe the GCCM EMAC including the different setups used for this work and the various data sets that will be compared with the simulations. The analysis of the five-year time slice simulations is presented and discussed in Sect. 3, followed by the investigation of the two single dust episodes simulated with the most appropriate setup in Sect. 4. Section 5 contains the summary and conclusions.

\section{Model and data}

\subsection{The Global Chemistry Climate Model EMAC}

The GCCM EMAC couples the 5th generation European Centre Hamburg GCM (ECHAM5) (Röckner et al., 2006) to the Modular Earth Submodel System (MESSy) (Jöckel et al., 2005, 2010). Independent of the horizontal resolu- tion all simulations presented in this study employ a vertical resolution of 31 layers with the top of the atmosphere at $10 \mathrm{hPa}$. In EMAC the emission, the deposition and ageing processes of aerosols are calculated in the following submodels: online emissions (ONLEM, Kerkweg et al., 2006b), scavenging (SCAV, Tost et al., 2006), sedimentation (SEDI) and dry deposition (DRYDEP, Kerkweg et al., 2006a). For this study we used the microphysical aerosol model M7 (Vignati et al., 2004), implemented as described by Kerkweg et al. (2008). M7 describes the aerosol distribution by four soluble and three insoluble log-normal modes. Freshly emitted dust particles are assumed to be always insoluble and can belong to the accumulation and the coarse mode. They become soluble either by intermodal coagulation or due to the condensation of sulphuric acid. Wet deposition is the most important removal process for dust. Soluble particles are scavenged more efficiently than insoluble ones. Hence, reasonable sulphur chemistry is required to move dust particles from the insoluble modes to the respective soluble mode. Gas phase chemistry is simulated by MECCA (Module Efficiently Calculating the Chemistry of the Atmosphere, Sander et al., 2011). A simulation with T42 resolution without any sulphurous species produced an unrealistic, almost homogeneous global dust distribution. Further tests indicated that not the most complex, and therefore computationally most expensive, chemistry setup is needed to simulate a reasonable global dust distribution. The minimum requirements in terms of chemistry are to include basic sulphur chemistry in order to correctly represent the ageing processes of the dust particles. The chosen chemistry setup contains 44 gas phase and 13 photolysis reactions including $\mathrm{HO}_{X}, \mathrm{NO}_{X}$, and sulphur chemistry. The full chemical mechanism is listed in the electronic Supplement: "The Basic Sulphur Chemical Mechanism of MECCA".

The entire dust cycle in the model crucially depends on the dust emission scheme. The default emission scheme in EMAC is described in Balkanski et al. (2004). Besides the Balkanski scheme (BK from now on) a second dust emission scheme has been implemented for this study to quantify the effect of the emission scheme. As second scheme the one by Tegen et al. (2002), in the following referred to as TG, was chosen. Both schemes are also implemented in the ECHAM5-HAM model (Stier et al., 2005). Despite the fact that both models, EMAC and ECHAM5-HAM, are based on the same GCM (i.e. ECHAM5) they differ with respect to the implementation of the aerosol modifying processes, e.g., the removal processes (sedimentation, dry and wet deposition) and the chemistry. Both BK and TG calculate the dust emission online in every time step, i.e., in response to prognostic model variables. BK requires three external input fields: threshold $10-\mathrm{m}$ wind velocity $\left(v_{\text {thr }}\right)$, source strength factor (SSF), and clay content (Kerkweg et al., 2006b). Balkanski et al. (2004) derived their parametrisation by using the $v_{\text {thr }}$ from Marticorena and Bergametti (1995) and the database of soil types from the Food and Agricultural Organization of 
Table 1. Input parameters for the dust emission schemes of Balkanski et al. (2004) and Tegen et al. (2002) for the Bodélé Depression and the Thar Desert.

\begin{tabular}{|c|c|c|c|c|}
\hline Emission scheme & Parameter & & Bodélé Depression & Thar Desert \\
\hline \multirow{2}{*}{ Balkanski et al. (2004) } & $v_{\mathrm{thr}}, \mathrm{m} \mathrm{s}^{-1}$ & & 7.2 & 6.0 \\
\hline & SSF & & $0.30 \times 10^{-9}$ & $1.08 \times 10^{-9}$ \\
\hline \multirow{7}{*}{ Tegen et al. (2002) } & $v_{\mathrm{thr}}, \mathrm{m} \mathrm{s}^{-1}$ & & 6.2 & 6.2 \\
\hline & LAI & & 0.00 in each month & $\begin{array}{l}\text { varies from } 0.43 \text { (Jan) to } \\
0.27 \text { (Jun, Jul, Aug) }\end{array}$ \\
\hline & \multirow{5}{*}{ soil texture class } & Coarse & 1.00 & 0.14 \\
\hline & & Coarse-medium & 0.00 & 0.06 \\
\hline & & Medium & 0.00 & 0.26 \\
\hline & & Medium-fine & 0.00 & 0.54 \\
\hline & & Fine & 0.00 & 0.00 \\
\hline
\end{tabular}

the United Nations (http://www.fao.org). Parameters were adjusted such that the simulated optical depth matches with the optical depth corrected from the TOMS aerosol index (Balkanski et al., 2004; Stier et al., 2005). No dust particles are emitted if the soil is too wet. The clay content is used to calculate the drying rate of the soil as a function of recent precipitation and surface temperature, as clay retains water for a longer time than other soil types. Hence, the higher the clay content, the longer it takes surface soil to dry. For each desert grid point, where the soil is dry enough, the vertical dust emission flux (VDEF) is calculated as a function of $v_{\mathrm{thr}}$, SSF and, the $10-\mathrm{m}$ wind velocity $\left(v_{10} \mathrm{~m}\right)$ according to:

$\mathrm{VDEF}=\operatorname{SSF} \cdot\left(v_{10 \mathrm{~m}}-v_{\mathrm{thr}}\right) \cdot\left(v_{10 \mathrm{~m}}\right)^{2}$.

The emitted dust aerosol is described as a log-normal size distribution with a mass mean radius (mmr) of $1.25 \mu \mathrm{m}$ and a standard deviation $(\sigma)$ of $2 \mu \mathrm{m}$.

The scheme of Tegen is much more complex (see Tegen et al. (2002), Stier et al. (2005), and Cheng et al. (2008) for details): In return, it provides more information about the dust emission, which is calculated from 192 internal dust size classes $i$ ranging from 0.2 to $1300 \mu \mathrm{m}$ in diameter. For each class an individual threshold friction velocity $\left(u_{* \text { thr }}(i)\right)$ is specified. The soil of each dust source grid box consists of a varying portion of four soil types: clay, silt, medium/fine sand, and coarse sand. In addition, preferential source regions (dried paleolake beds) are prescribed that are particulary active for $10-\mathrm{m}$ wind speeds above $10 \mathrm{~m} \mathrm{~s}^{-1}$. From these soil texture classes, required as input fields, the relative surface area $\left(s_{i}\right)$ covered by each dust size class $i$ is computed. The horizontal particle flux (HPF) is then calculated for each $i$ as follows:

$\operatorname{HPF}(i)=\frac{\rho_{a}}{g} \cdot u_{*}^{3} \cdot\left(1+\frac{u_{* \operatorname{thr}}(i)}{u_{*}}\right) \cdot\left(1-\frac{u_{* \mathrm{thr}}^{2}(i)}{u_{*}^{2}}\right) \cdot s_{i}$

if $u_{*} \geq u_{* \operatorname{thr}}(i), \quad(\operatorname{HPF}(i)=0$, otherwise $)$, with $\rho_{a}$ the air density, $g$ the gravitational constant, and $u_{*}$ the surface wind stress that is calculated from the prognostic $10-\mathrm{m}$ wind speed. The horizontal fluxes are turned into the respective vertical dust emission fluxes VDEF by:

$\operatorname{VDEF}(i)=\alpha \cdot f(\mathrm{LAI}) \cdot \operatorname{HPF}(i) \cdot I_{\Theta}$,

where $\alpha$ describes the soil texture characteristics. For the Leaf Area Index (LAI) monthly mean values are prescribed. The LAI-dependent function takes into account that the flux increases or decreases depending on the vegetation. $I_{\Theta}$ is 0 if the ratio of prognostic soil moisture to the field capacity is higher than 0.99 and 1 otherwise (Tegen et al., 2002). The vertical emission fluxes of the single size classes are summed up to get a bimodal dust emission with an insoluble accumulation mode $(\mathrm{mmr}=0.37 \mu \mathrm{m}, \sigma=1.59 \mu \mathrm{m})$ and an insoluble coarse mode $(\mathrm{mmr}=1.75 \mu \mathrm{m}, \sigma=2 \mu \mathrm{m})$ (Cheng et al., 2008).

As an example the values of the input fields of two prominent dust source regions, the Bodélé Depression in Chad and the Thar Desert in North-West-India, are shown in Table 1. With BK $10-\mathrm{m}$ wind speeds of more than $7.2 \mathrm{~m} \mathrm{~s}^{-1}$ are necessary to mobilise particles from the Bodélé Depression while only $6 \mathrm{~m} \mathrm{~s}^{-1}$ are required in the Thar Desert. The SSF is about 3.5 times higher in Thar than in Bodélé. With the TG scheme the $10-\mathrm{m}$ threshold velocity is $6.2 \mathrm{~m} \mathrm{~s}^{-1}$ in both regions. The LAI for TG varies from 0.27 to 0.43 over the year in the Thar Desert where the soil consists mainly of mediumfine and medium particles. In the Bodélé Depression LAI is constantly 0 and the particles are assumed to be in the coarse texture class.

How these two very different schemes behave dependent on the region and the 10-m wind speed is shown in Fig. 1 . For this example the soil wetness is set to 0 . The two schemes produce similar fluxes in the Bodélé Depression for $10-\mathrm{m}$ wind speeds up to $10 \mathrm{~m} \mathrm{~s}^{-1}$. Higher velocities cause higher emissions with TG because the Bodélé Depression is 


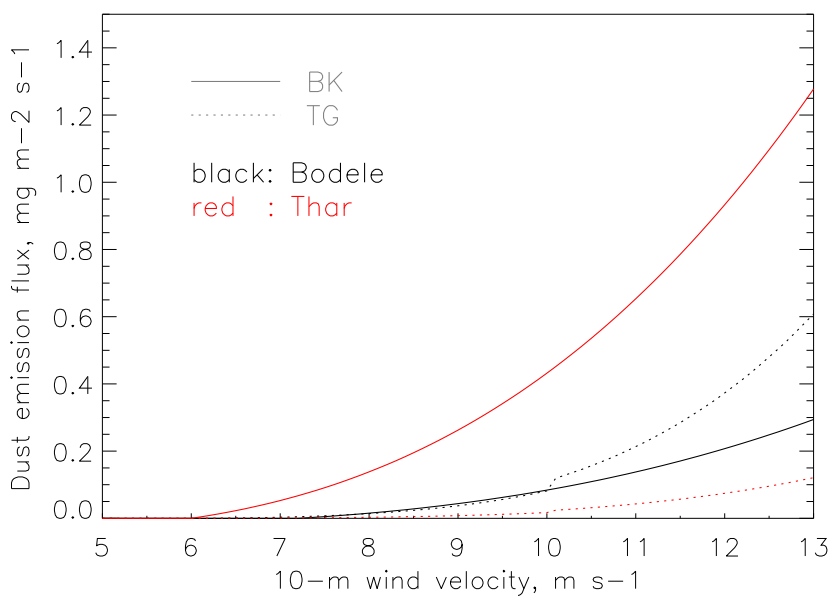

Fig. 1. Vertical dust emission flux $\left(\mathrm{mg} \mathrm{m}^{-2} \mathrm{~s}^{-1}\right)$ vs. 10-m wind velocity $\left(\mathrm{m} \mathrm{s}^{-1}\right)$ as simulated with the two dust emission schemes by Balkanski et al. (2004) (solid lines) and Tegen et al. (2002) (dotted lines) in the Bodélé Depression (black) and the Thar Desert (red).

a classic example of a paleolake preferential dust source area (Tegen et al., 2002). The differences in the Thar Desert are enormous. The relatively low $v_{\text {thr }}$ and the high SSF cause very strong emissions with $\mathrm{BK}$.

\subsection{Comparison datasets}

To validate the EMAC simulations we used the following observational and model data sets.

\subsubsection{Long-term in situ measurements}

The results of the time slice simulations will be compared to measured dust deposition fluxes and surface dust concentrations at selected sites (see Table S1 in the electronic Supplement). Deposition data are taken from Ginoux et al. (2001), Tegen et al. (2002), and Mahowald et al. (2009), surface dust concentrations from Stier et al. (2005) and Mahowald et al. (2009). The measurements from cruises are not considered here because they do not represent annual values. Also measurements of iron concentrations are omitted to avoid uncertainties from the assumption that dust contains 3.5\% iron (Mahowald et al., 2009). All together, this provides deposition and concentration measurements at 91 and 47 sites, respectively, which will be compared to the simulated values at the grid box containing the measurement site in Sect. 3.1.

\subsubsection{MODIS aerosol mass concentration}

Fields of the columnar aerosol mass concentration measured by MODIS (Moderate Resolution Imaging Spectroradiometer) with $1^{\circ} \times 1^{\circ}$ grid spacing are provided via the web interface http://gdata1.sci.gsfc.nasa.gov/daac-bin/ G3/gui.cgi?instance_id=MODIS_DAILY_L3. The retrieval algorithms are described by Remer et al. (2005). For the evaluation of the presented time slice simulations, the seasonal mean values of the MODIS mass concentration are calculated using data from 1 March 2000 to 28 February 2005.

\subsubsection{The Saharan Mineral Dust Experiment SAMUM}

During the SAMUM 2006 field campaign (see Heintzenberg (2009) and the special issue Tellus Ser. B-Chem. Phys. Meteorol., Vol. 61) physical and chemical properties of desert aerosols were measured in southern Morocco near Tinfou $\left(30^{\circ} 14^{\prime}\right.$ N, $5^{\circ} 36^{\prime}$ W, $684 \mathrm{~m}$ a.s.l.) (Kandler et al., 2009; Knippertz et al., 2009). In Sect. 4.1 the measured concentrations of the total suspended particle matter (TSP, 12-hourly measurements most of the time) and of particles smaller than $10 \mu \mathrm{m}\left(\mathrm{PM}_{10}\right.$, daily measurements) are compared to the simulated dust concentration for the entire measurement period from 12 May to 6 June 2006.

\subsubsection{Measurements at Mt. Kleiner Feldberg, Germany}

The number concentration of ice nuclei (IN) and $\mathrm{PM}_{10}$ concentrations have been measured since April 2008 at the Taunus Observatory of the Goethe-University of Frankfurt/Main on Mt. Kleiner Feldberg in Germany $\left(50^{\circ} 13^{\prime} \mathrm{N}\right.$, $8^{\circ} 27^{\prime} \mathrm{E}, 825 \mathrm{~m}$ a.s.l.) (Klein et al., 2010). In Sect. 4.2 we compare the measurements with the simulated dust concentration for the period from 23 May to 4 June 2008, which contains the strongest event of Saharan dust advection to Germany during the years 2006-2010 (Klein et al., 2010).

\subsubsection{Satellite (MSG) dust RGB composite}

Particular combinations of different channels of the Meteosat Second Generation (MSG) satellite allow for the visualisation of single atmospheric compounds. The red-greenblue (RGB) composite of the SEVIRI (Spinning Enhanced Visible and InfraRed Imager) IR8.7, IR10.8, and IR12.0 channels shows dust aerosol in magenta colours. More information about the MSG dust RGB composite can be found in the online documentation (http://oiswww.eumetsat. org/SDDI/html/doc/dust_interpretation.pdf, 22 June 2011). These images are used to evaluate the EMAC simulation of the SAMUM episode.

\subsubsection{The regional dust model BSC/DREAM8b}

Additionally, short-range forecasts of the Dust REgional Atmospheric Model (DREAM) are used for comparison with EMAC for the two episodes. DREAM simulates the atmospheric dust cycle with the emission scheme of Shao and Raupach (1993) modified by Janjic (1994) and Fécan et al. (1999). The model version $8 \mathrm{~b}$ has a horizontal resolution of $50 \times 50 \mathrm{~km}$ and 24 layers extending up to $15 \mathrm{~km}$. For further details see Nickovic et al. (2001), Pérez et al. (2006a,b), and http://www.bsc.es/plantillaH.php?cat_id=322. 
Table 2. Skill scores resulting from the comparison of the eight time slice simulations with in situ measurements of dust deposition and surface dust concentration from Ginoux et al. (2001), Tegen et al. (2002), Stier et al. (2005), and Mahowald et al. (2009).

\begin{tabular}{lrrrr}
\hline & Bias & MNB & LMNB & NRMS \\
\hline T42BK & -5.59 & 3.98 & 0.04 & 15.39 \\
T63BK & -4.56 & 4.92 & 0.07 & 19.36 \\
T85BK & -4.11 & 3.45 & -0.08 & 15.51 \\
T106BK & -4.05 & 7.13 & -0.02 & 31.11 \\
\hline T42TG & -3.91 & 6.26 & 0.20 & 23.43 \\
T63TG & -2.36 & 7.32 & 0.17 & 30.43 \\
T85TG & -2.09 & 4.95 & 0.00 & 22.08 \\
T106TG & 1.95 & 7.00 & 0.14 & 29.25 \\
\hline
\end{tabular}

\section{Evaluation of five-year time slice simulations with EMAC}

In this section, the entire dust cycle of the five-year time slice simulations is analysed with respect to the horizontal model resolution (T42, T63, T85, and T106) and the dust emission scheme (BK and TG). The aim is to determine the model setup that produces the most reasonable mineral dust cycle.

Simulations in earlier climate epochs are planned for the future, for which no analysis data are available. To ensure comparability of the simulations in different climate epochs, no "nudging" towards realistic meteorology is applied in the here presented simulations.

\subsection{Comparison with dust measurements}

For the eight time slice simulations different skill scores determined by the measurements of dust deposition and surface dust concentration, described in Sect. 2.2.1, are listed in Table 2. The bias, the mean normalised bias (MNB), the log-mean normalised bias (LMNB), and the normalised root mean square error (NRMS) that are defined as in Lee et al. (2009) and Huneeus et al. (2011), are considered here. A scatter plot of simulated versus measured values for the different setups is provided in Fig. S1 in the Supplement. The interpretation of Table 2 is not straight forward because different setups yield the best results for different skill scores. For instance, T42BK is the worst setup with regard to the bias, but it is the best one considering the NRMS. The bias of all simulations using the BK scheme is worse compared to the simulations with the TG scheme but on average they perform better with regard to the MNB, the LMNB, and the NRMS. Hence, no final decision on the preferred dust emission scheme is made from this analysis alone. Additionally, a clear dependence of the results on the horizontal resolution is lacking. Because measurements at single stations are compared with grid box values here, it is possible that finer resolutions are subject to the double penalty problem. Among the simulations with the TG scheme, it is remarkable that T85 yields the best results for three of the four skill scores but from Table 2 alone no conclusion can be drawn which setup performs best.

\subsection{Global dust budget}

Table 3 shows the five-year means of the global dust emission, load, life time, total and wet deposition and the ratio of wet to total deposition as simulated by EMAC using T42, T63, T85, and T106 spectral resolutions. For each resolution the results with the two emission schemes BK and TG are listed. The total dust deposition does not deviate more than $2 \%$ from the emissions and there is no trend in the dust load over the five years showing that the dust budget is closed. The life time is calculated as the ratio of dust load to total dust deposition. For the eight different setups, the emissions range from 1651 to $3238 \mathrm{Tg} \mathrm{yr}^{-1}$, the load from 22.18 to $36.20 \mathrm{Tg}$ and the life time from 3.98 to 6.19 days. We first note that all the values of the dust emission and life time are within the very wide range of earlier estimates based upon model simulations (AEROCOM: Textor et al., 2006; Huneeus et al., 2011). The dust load, however, exceeds this range in the T63BK, T85BK, T106BK, and T106TG simulations.

\subsection{Geographical dust distribution}

The global distribution of dust emissions and loads of the eight experiments are illustrated in Figs. 2 and 3, respectively. At first sight, each setup produces reasonable distributions. A closer look at single regions reveals interesting differences. Independent of the model resolution BK simulates the global maximum of the emissions in northwest India, leading to the global maximum in the loads in the same region (left column in Figs. 2 and 3). For the same location emissions of the TG scheme are in general much lower (right column in Fig. 2) and comparable to the values at other hotspots like the Bodélé Depression in Chad (middle column in Figs. 2 and 3). According to other studies, the Sahara is the major dust source in the world (Prospero et al., 2002; Washington et al., 2003; Ginoux et al., 2004). The averaged dust emission of the four simulations with BK accounts for $608 \mathrm{Tg} \mathrm{yr}^{-1}$ in the Sahara $\left(5^{\circ}-36^{\circ} \mathrm{N}, 20^{\circ} \mathrm{W}\right.$ $\left.-40^{\circ} \mathrm{E}\right)$ and $1483 \mathrm{Tg} \mathrm{yr}^{-1}$ in India $\left(20^{\circ}-33^{\circ} \mathrm{N}, 65^{\circ}-85^{\circ}\right.$ E). This means that the dust emissions in India are 2.4 times higher than in the Sahara, which is in clear contradiction to the studies mentioned above. Very strong emissions in India in the BK scheme result from a relatively low 10-m wind speed threshold and a pretty high source strength factor in this region compared to values in the Sahara (see Sect. 2.1, in particular the discussion of Fig. 1). TG on average simulates $925 \mathrm{Tg} \mathrm{yr}^{-1}$ in the Sahara and $169 \mathrm{Tg} \mathrm{yr}^{-1}$ in India. Stier et al. (2005) also mentioned the higher emissions in the Thar Desert with the BK scheme compared to the TG scheme. 
(a)

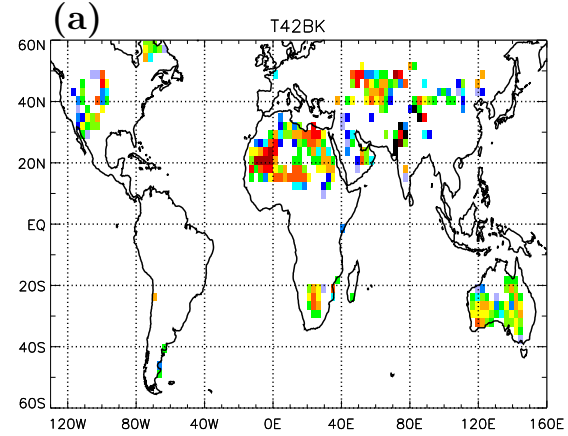

(b)

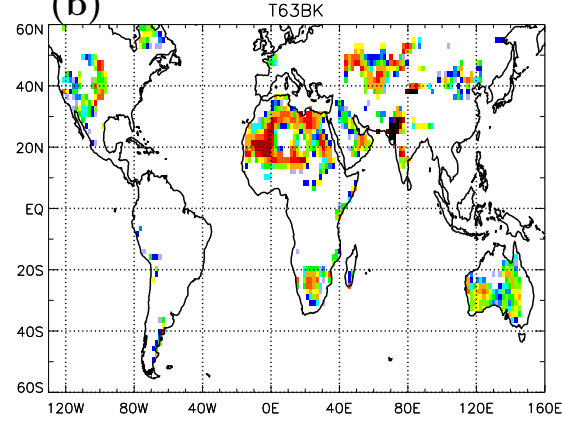

(c)

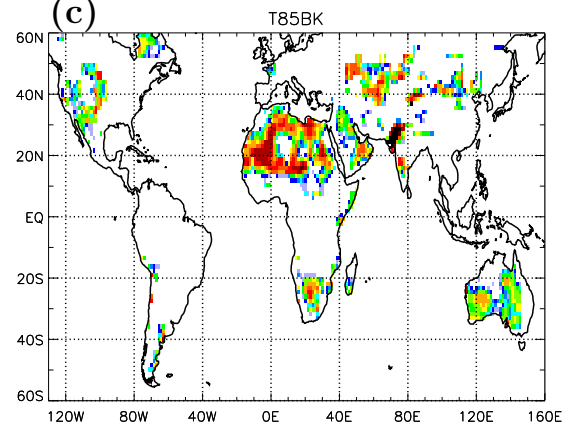

(d)

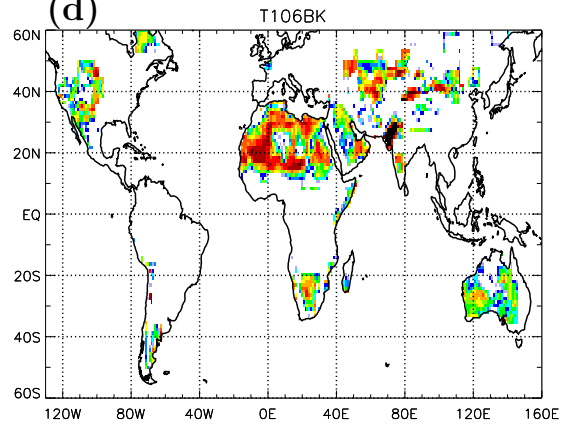

(e)

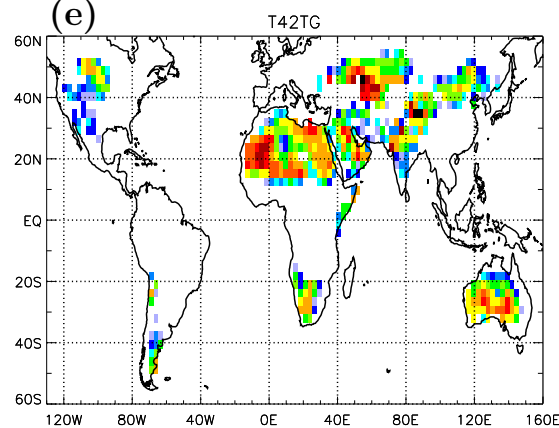

(f)

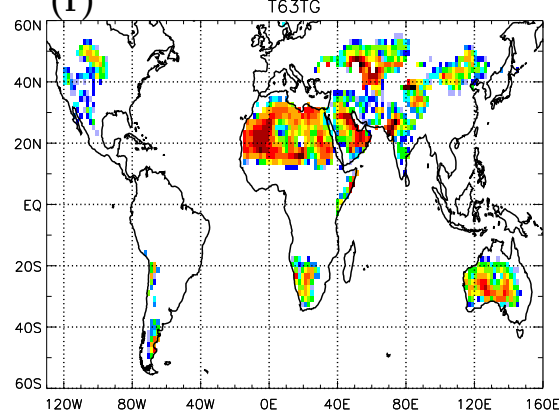

(g)

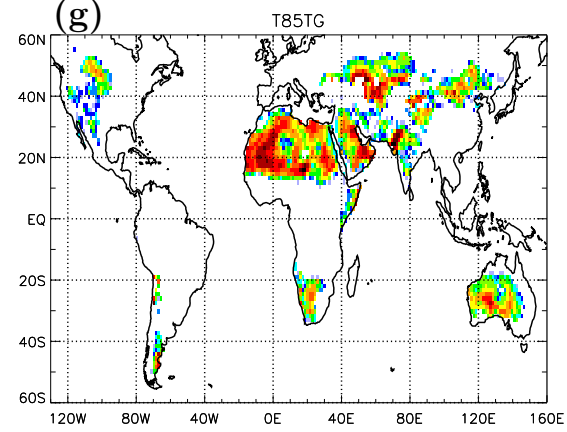

(h)

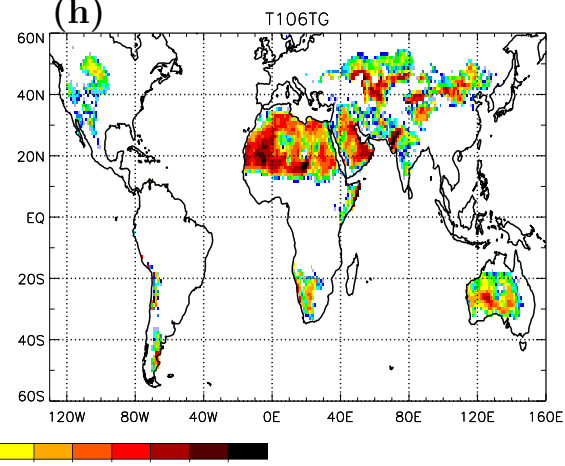

(j)

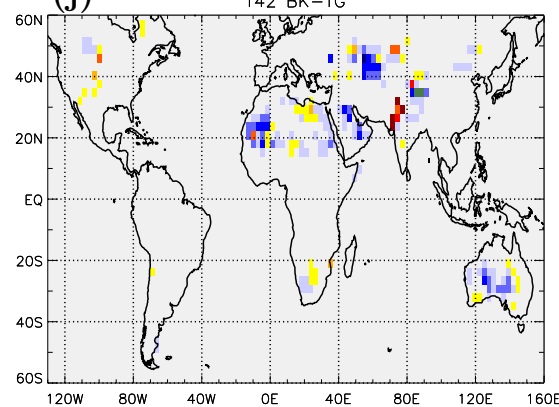

(k)

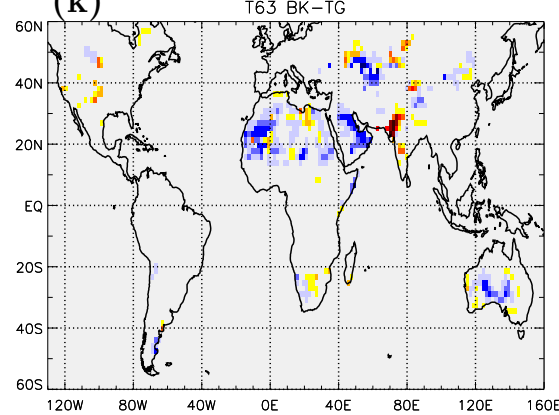

(m)

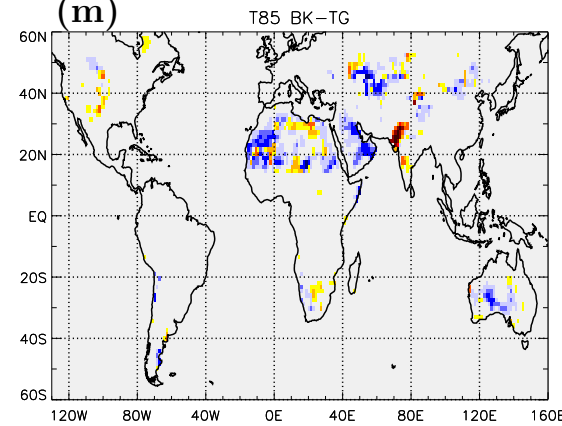

(n)

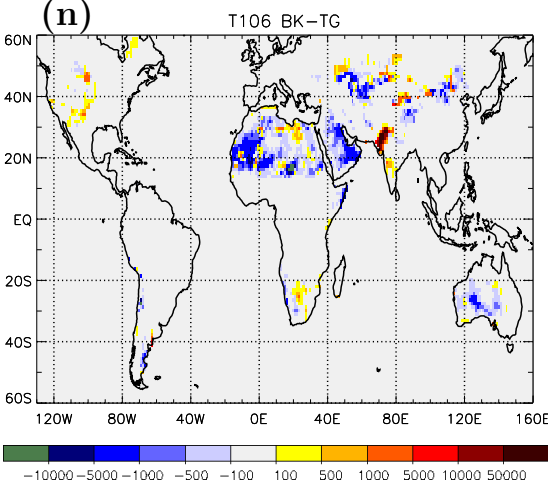

Fig. 2. Simulated five-year mean dust emission $\left(\mathrm{kg} \mathrm{ha}^{-1} \mathrm{yr}^{-1}\right)$ using the dust emission schemes of Balkanski et al. (2004) (left column) and Tegen et al. (2002) (middle column) and for the spectral model resolutions T42 (1st row), T63 (2nd row), T85 (3rd row), and T106 (4th row). The right column shows the difference of BK minus TG. 
(a)

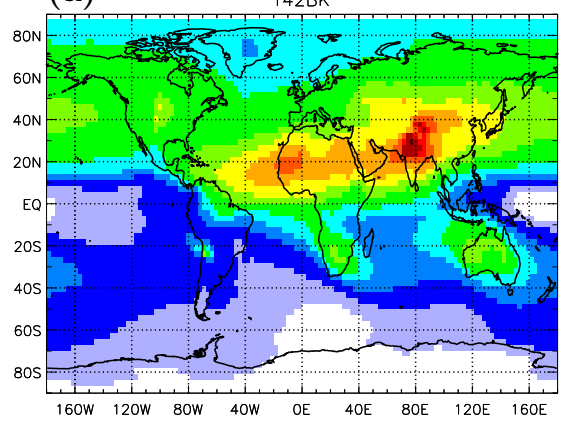

(b)

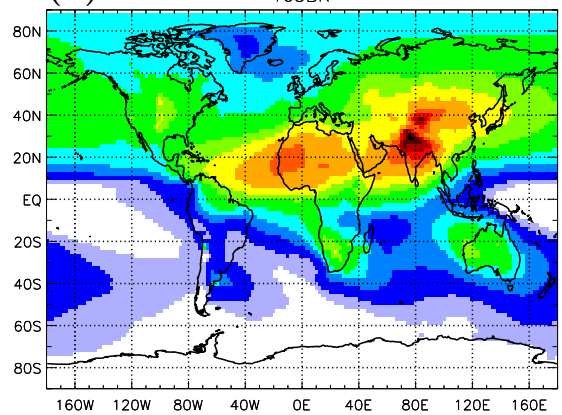

(c)

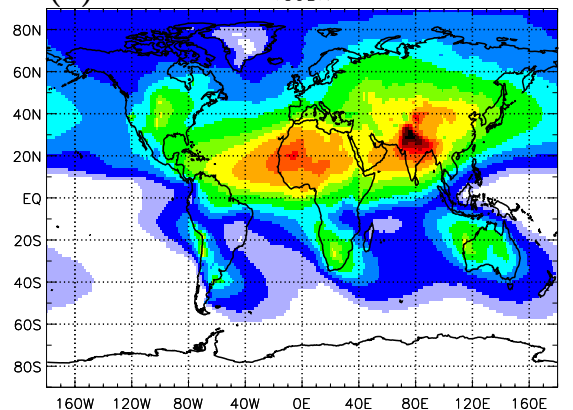

(d)

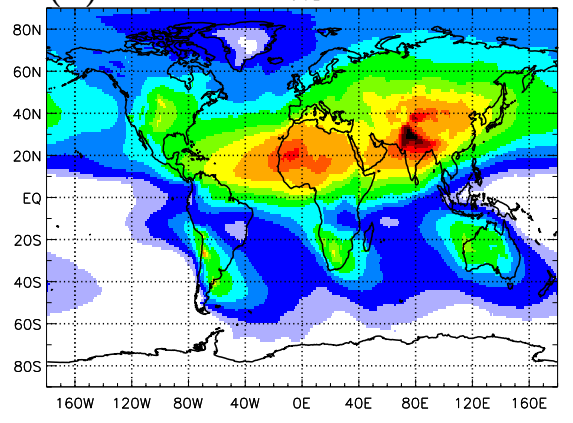

(e)

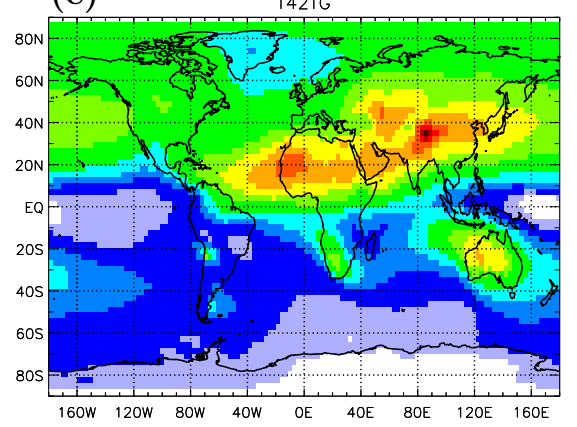

(f)

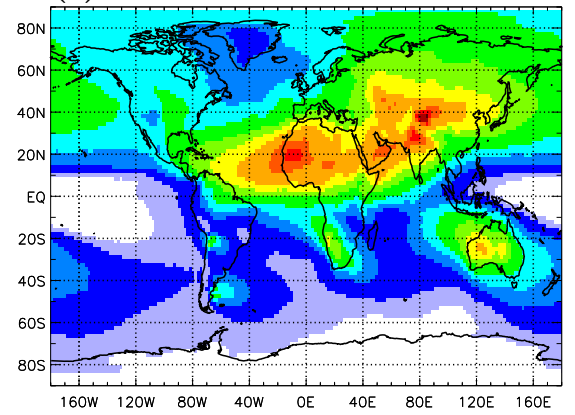

(g)

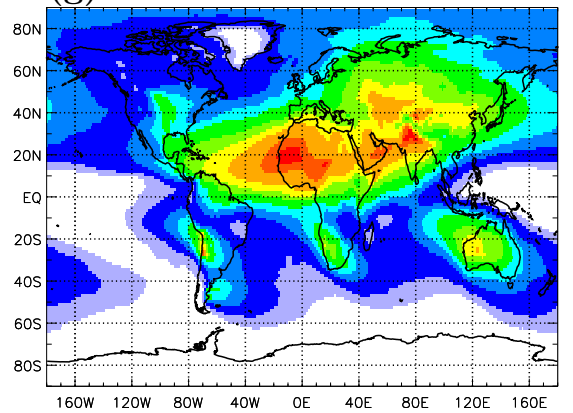

(h)

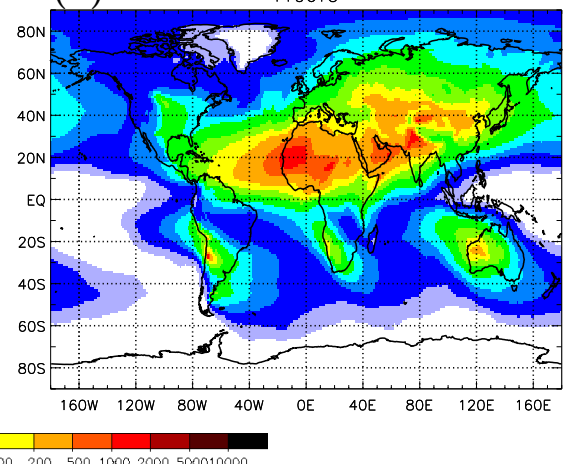

$(\mathrm{j})$

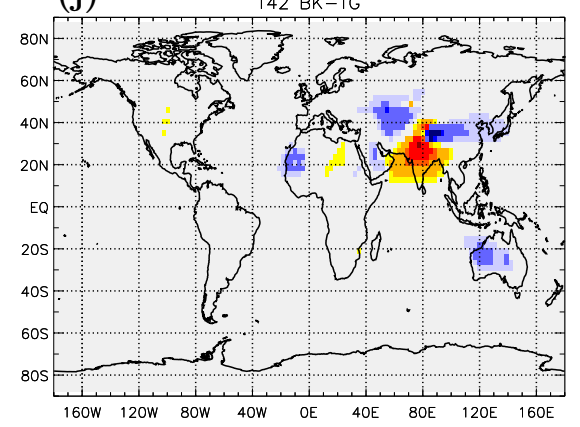

(k)

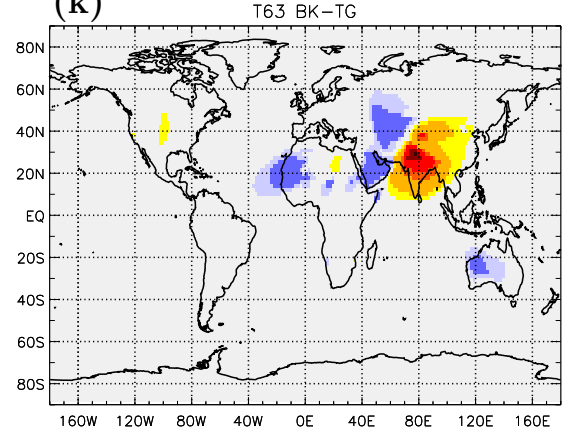

(m)

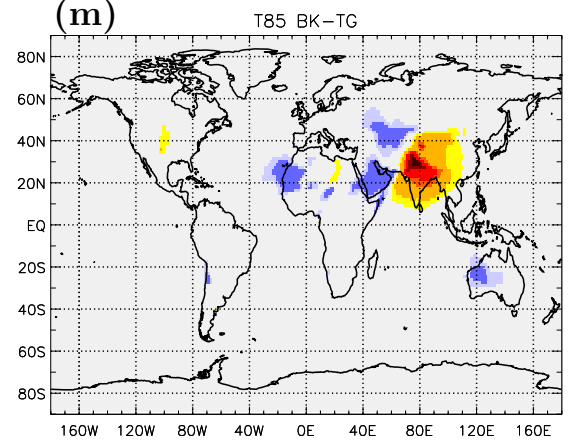

(n)

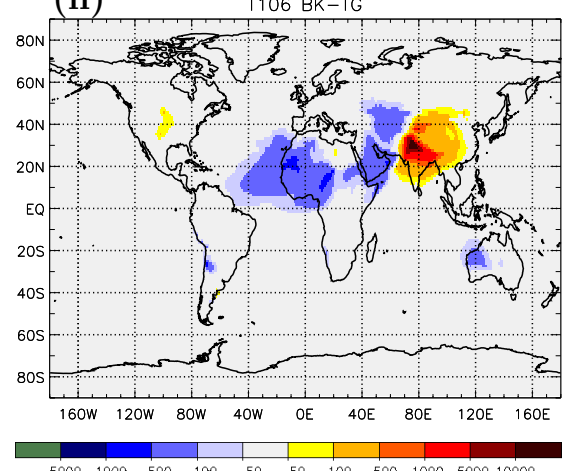

Fig. 3. Simulated five-year mean dust column mass $\left(\mathrm{mg} \mathrm{m}^{-2}\right)$ using the dust emission schemes of Balkanski et al. (2004) (left column) and Tegen et al. (2002) (middle column) and for the spectral model resolutions T42 (1st row), T63 (2nd row), T85 (3rd row), and T106 (4th row). The right column shows the difference of BK minus TG. 
Table 3. Five-year mean values (2000-2004) of various dust parameters of the eight time slice simulations.

\begin{tabular}{lcccccc}
\hline & $\begin{array}{c}\text { emission } \\
\mathrm{Tg} \mathrm{yr}^{-1}\end{array}$ & $\begin{array}{c}\text { load } \\
\mathrm{Tg}\end{array}$ & $\begin{array}{c}\text { life time } \\
\text { days }\end{array}$ & $\begin{array}{c}\text { total deposition } \\
\mathrm{Tg} \mathrm{yr}^{-1}\end{array}$ & $\begin{array}{c}\text { wet deposition } \\
\mathrm{Tg} \mathrm{yr}^{-1}\end{array}$ & $\begin{array}{c}\text { wet } \\
\text { total deposition } \\
\%\end{array}$ \\
\hline T42BK & 1651 & 27.85 & 6.19 & 1644 & 1262 & 76.8 \\
T63BK & 2704 & 36.20 & 4.91 & 2693 & 2096 & 77.9 \\
T85BK & 2841 & 31.50 & 4.09 & 2813 & 2222 & 79.0 \\
T106BK & 3238 & 34.92 & 3.98 & 3208 & 2557 & 79.7 \\
\hline T42TG & 1683 & 26.63 & 5.85 & 1662 & 1046 & 62.9 \\
T63TG & 1975 & 27.34 & 5.12 & 1953 & 1174 & 60.1 \\
T85TG & 1815 & 22.18 & 4.55 & 1781 & 1068 & 59.9 \\
T106TG & 2673 & 31.55 & 4.41 & 2615 & 1588 & 60.7 \\
\hline
\end{tabular}

\subsection{Seasonal cycle and regional considerations}

The seasonal comparison of the simulated values of the dust column mass over the Indian subcontinent with MODIS aerosol column mass (not shown) reveals two problems of the BK scheme. Firstly, the simulations with the BK scheme strongly overestimate the column mass, especially during summer. MODIS measures $539 \mathrm{mg} \mathrm{m}^{-2}$ in JJA, $330 \mathrm{mg} \mathrm{m}^{-2}$ in MAM, $253 \mathrm{mg} \mathrm{m}^{-2}$ in SON, and $212 \mathrm{mg} \mathrm{m}^{-2}$ in DJF. T42BK overestimates the JJA value by a factor of 12 and the finer resolutions even by a factor of about 20. Also in MAM and SON the simulations with the BK scheme overestimate the column mass by a factor of 3-4 while there is a slight underestimation during DJF. Secondly, BK simulations and the MODIS measurements differ with respect to the seasonal cycle. Except for the T106 resolution, each simulation shows the second highest column mass in SON, not in MAM like MODIS. The simulations with the TG scheme reproduce the seasonal cycle correctly, independent of the horizontal resolution. The simulated values in JJA are less than three times higher than the MODIS column mass. The detection of aerosols by MODIS is affected by clouds (Remer et al., 2005). Habib et al. (2006) showed for the TOMS Aerosol Index that the presence of clouds could obscure the aerosol detection in this region leading to an underestimation of the aerosol load during the monsoon period from June to September. This could explain why the simulated values with the TG scheme are higher than the MODIS values.

As an example for the seasonal variation of the dust cycle over the Indian Subcontinent, Fig. 4 shows the dust emission and deposition and the wind on the lowest model layer of the T85TG simulation. In winter (DJF, Fig. 4a) the ITCZ lies south of the equator and the wind arrows over the Indian Ocean illustrate the north-easterly trade winds. During this season there is almost no dust activity in this region. In summer (JJA, Fig. 4b) the strong south-westerly trade winds mobilise a huge amount of dust when they make landfall in the region of the Thar Desert in the north-western part of India. The dust particles get washed out by the monsoon- related precipitation at the southern slope of the Himalayas. This effect causes the global maxima of the dust emission and deposition in this region in JJA.

Another region where the two dust emission schemes produce different emission is the northern part of Africa and the Arabian Peninsula. Here, on average, the TG scheme produces higher values (right column in Fig. 2). These higher emissions with TG, especially over north-western Africa, cause higher dust column masses locally and over the adjacent Atlantic Ocean. The difference between the two emission schemes is strongest in the T106 simulations, but its magnitude is still ten times lower than the differences over the Indian subcontinent. The results for the Sahara dust emissions are within the wide span of published values for each of the time slices (Washington et al., 2003; Ginoux et al., 2004; Huneeus et al., 2011). Prospero et al. (2002) described the seasonal cycle of the transatlantic transport of dust from North Africa: It is highest in JJA and reaches the Caribbean, while during DJF the dust is transported to South America. These seasonal transport patterns are reproduced in each simulation (not shown).

The Bodélé Depression in Chad is the world's most intense dust source and is active during the whole year (Prospero et al., 2002). However, the T42 simulations and T63BK do not show a distinct dust emission signal in this region (Fig. 2a, b, e). Prospero et al. (2002) also showed that the dust activity in DJF in North Africa is greatest in the low latitudes and moves to higher latitudes during the year. This behaviour is reproduced by all setups. The center of mass of the dust load is about $5^{\circ}$ further south in DJF than during JJA and SON.

The above analyses reveal that the major difference between the two dust emission schemes is positioned in the Thar Desert, while variations in other parts of the world are much smaller. Due to the strong overestimation of emissions in India with BK the TG scheme is overall regarded as the more reliable dust emission scheme for the EMAC model at resolutions between T42 and T106. 
(a)

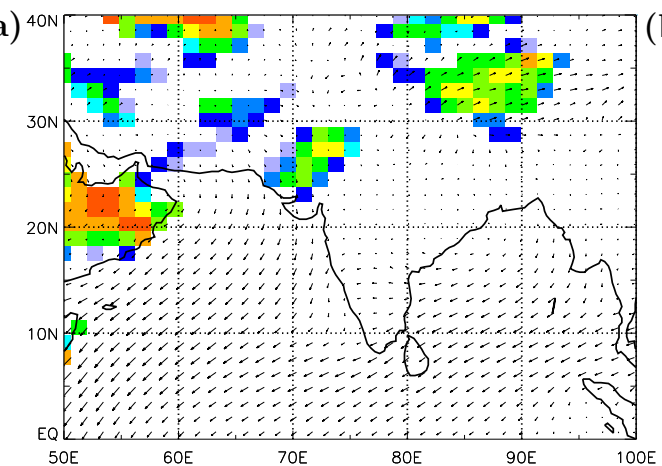

(b)
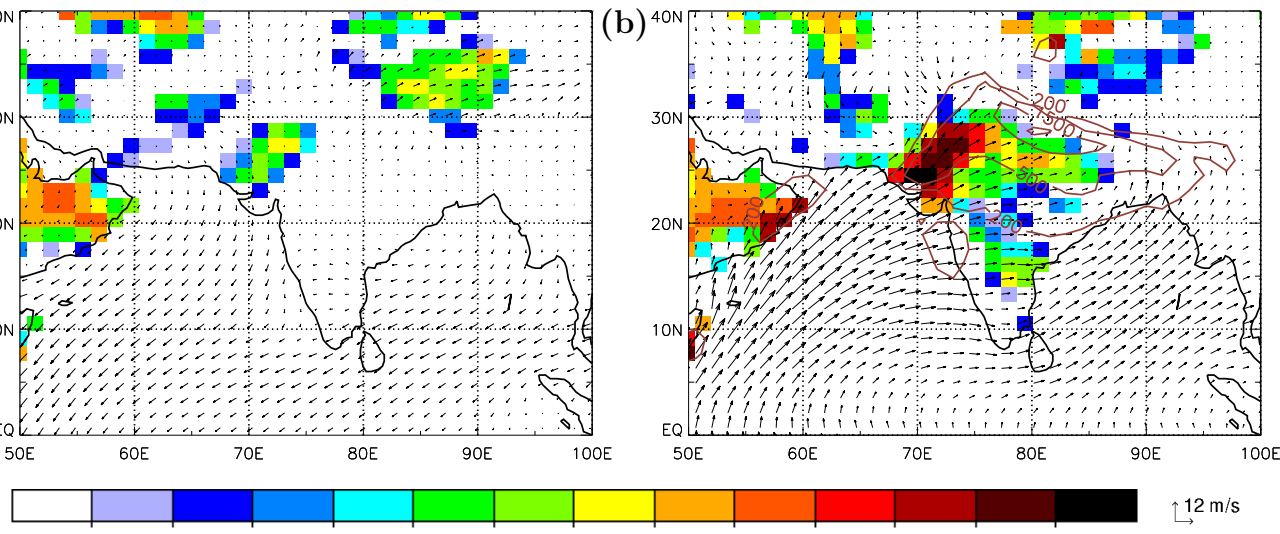

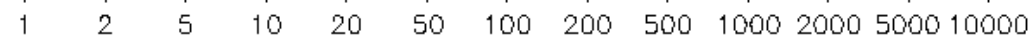

Fig. 4. Mean dust emission ( $\mathrm{kg} \mathrm{ha}^{-1}$, shading), deposition (brown isolines for 200, 500, 1500, and $3000 \mathrm{~kg}^{-1}$ ), and the wind on the lowest model layer (arrows) over the Indian subcontinent during DJF (a) and JJA (b) in the simulation T85TG.

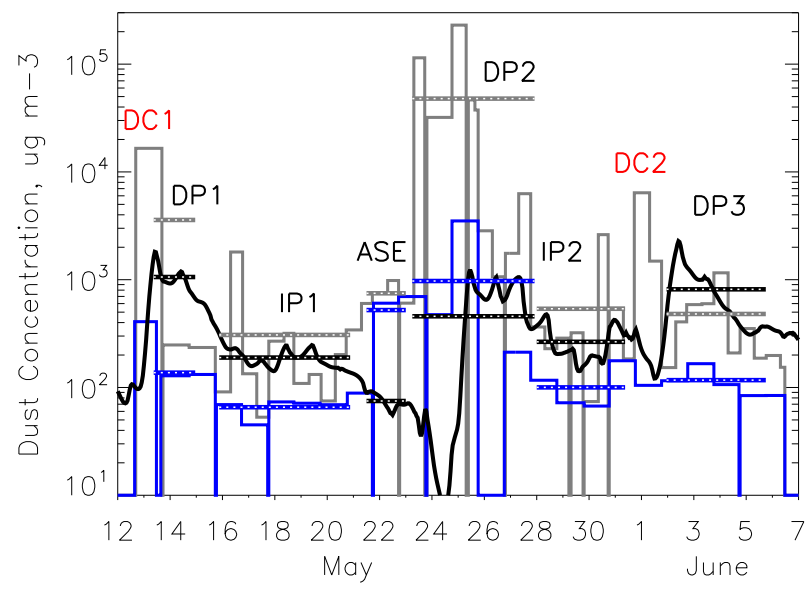

Fig. 5. Time series of the measured TSP (grey) and $\mathrm{PM}_{10}$ (blue) concentrations at Tinfou, Morocco and the simulated dust concentrations (black) in the grid box containing Tinfou with T85TG $\left(\mu \mathrm{g} \mathrm{m}^{-3}\right)$. Horizontal bars with white dotted lines on it show the mean values for the periods defined by Kandler et al. (2009), DC1 and DC2 mark the two density currents, observed during SAMUM.

Besides the differences in the global mean values (see Table 3) the model resolution influences the patterns of the dust emissions and loads. In addition to the problems in the Bodélé Depression, another weakness of the coarse resolutions T42 and T63 arises in Central Asia. For both emission schemes T42 and T63 generate some grid points with pretty high emissions in the area of the Taklamakan Desert in the Tarim Basin north of the Himalayas (Figs. 2a, b, e, f). The mean emission with $\mathrm{T} 42$ and T63 within the small box $\left[34^{\circ}-40^{\circ} \mathrm{N}, 75^{\circ}-95^{\circ} \mathrm{E}\right]$ is about half of the mean emission in entire North Africa. This causes very high dust loads in polar regions of more than $10 \mathrm{mg} \mathrm{m}^{-2}$ north of $80^{\circ} \mathrm{N}$ (Fig. 3a, $\mathrm{b}$, e, f). The mean load of all AEROCOM models is less than $5 \mathrm{mg} \mathrm{m}^{-2}$ in this region (http://dataipsl.ipsl.jussieu.fr/
cgi-bin/AEROCOM/aerocom/surfobs_annualrs.pl, choose as Species: DUST and as Parameter: LOAD, 22 June 2011) but $10 \mathrm{mg} \mathrm{m}^{-2}$ is still within the wide range of the AEROCOM models. Comparison to the MODIS column mass provides strong evidence that the emissions in the Taklamakan Desert and column masses in high northern latitudes with T42 and T63 are too high. The dust sources in Central Asia are most active in spring (Tegen et al., 2002; Geng et al., 2009). The mean value of the MODIS column mass in the region $35^{\circ}-55^{\circ} \mathrm{N}, 50^{\circ}-110^{\circ} \mathrm{E}$ accounts for $238 \mathrm{mg} \mathrm{m}^{-2}$ in MAM, $217 \mathrm{mg} \mathrm{m}^{-2}$ in JJA, $157 \mathrm{mg} \mathrm{m}^{-2}$ in DJF, and $150 \mathrm{mg} \mathrm{m}^{-2}$ in SON. Independent of the emission scheme the T42 and T63 simulations produce the maximum in JJA, with an overestimation of the column mass by a factor of 3-4.5. T85TG and T106TG reproduce the seasonal cycle correctly and the values do not deviate more than $50 \%$ from the MODIS column mass. T85BK and T106BK simulate the maximum also in MAM, followed by JJA. However, the minimum is produced in DJF with an underestimation of the MODIS values by a factor of 2-3. The strong emissions in the Taklamakan Desert with T42 and T63 occur due to a combination of an orographic effect and the coarse resolution. At the steep northern slope of the Himalayas the model produces pretty high near-surface wind velocities at elevated grid points. Due to the coarse resolution some of these grid points are preferential dust source regions. In T85 and T106 it becomes possible to distinguish between elevated grid points with high winds and those in the basin, which are the dust source grid points. Because of these deficiencies - unrealistically high emissions in the Tarim Basin that cause too high dust loads in the Arctic - model simulations with T42 and T63 produce a less realistic global dust cycle than T85 and T106. 


\subsection{Final decision and further insight}

So far, the analyses revealed some distinct shortcomings in simulating the global mineral dust cycle with each setup except T85TG and T106TG. However, the quantitative differences between T85 and T106 with the TG scheme are substantial: Mean dust emissions and loads are almost $50 \%$ higher in T106 than in T85. The higher emissions are caused by differences in the $10-\mathrm{m}$ wind velocities at dust source grid points, where the mean wind speed is on average $3.5 \%$ higher in T106 than in T85. Nevertheless, the global distributions look quite similar (see Figs. $2 \mathrm{~g}, \mathrm{~h}$ and $3 \mathrm{~g}, \mathrm{~h}$ ) and appear reasonable, compared to the AEROCOM mean dust emission and column mass. Both simulations produce dust emissions and life times that are within the range of earlier estimates but the dust load of T106TG (31.6 Tg) exceeds the range of the AEROCOM models (6.8-29.5 Tg). Considering all this, and because of the better performance of T85TG in comparison with the measurements of dust deposition and surface concentration (see Table 2), the T85 setup with the TG scheme is the one to prefer for long-term climate simulations with the EMAC model system.

Some other interesting aspects can be obtained from Table 3. With BK, dust emissions increase and life times decrease with increasing model resolution. The dust load, however, is lower in T85BK and T106BK than in T63BK although the emissions are higher leading by definition to the shorter life times. With TG the life times show the same trend as with BK, the dust emissions also increase with finer resolution except in T85TG where the emission is lower than in T63TG. The same is true for the dust load, which is in T85TG even lower than in T42TG. One possible explanation for the decreasing life times from T42 to T106 is the increase in the maximum near surface wind speed in finer resolutions. This is confirmed by the ratio "total deposition close to source regions" to "global total deposition", which increases with finer resolution. With both emission schemes the wet-to-total deposition rate is hardly dependent on the resolution but it is generally higher with $\mathrm{BK}(\approx 78 \%)$ than with TG $(\approx 60 \%)$. With the BK scheme there is very strong wet deposition of the dust emitted in the Thar Desert. This signal dominates when calculating the overall wet-to-total deposition rate. If the evaluation is limited to the domain outside the Thar region, simulations with the BK and the TG scheme produce both a similar fraction of wet deposition (60-70\%). This indicates that wet deposition is particularly important for dust from certain emission regions, and consequently, that emission schemes with stronger emissions in these regions contribute to a larger fraction of the overall wet deposition.

\section{Two single dust episodes simulated with T85TG}

The intensity of dust emission varies dependent on the meteorological situation. Single dust outbreaks, lasting a few days, can contribute a large amount to the annually emitted dust from a certain region. In this section the ability to reproduce such events with EMAC using the T85TG setup is investigated. To compare simulations with measurements the model was nudged to reanalysis data of the European Centre for Medium-range Weather Forecasting (ECMWF). The nudging through the Newtonian relaxation of the four prognostic model variables temperature, divergence, vorticity, and the logarithm of surface pressure is only applied in the free troposphere (Jöckel et al., 2006). The nudging has the potential to influence the climatological values of different model variables. For instance, the 10-m wind speed distribution in the ECHAM4 is shifted in a nudged simulation compared to a free running one, which causes higher dust load and shorter life time in the free running mode (Timmreck and Schulz, 2004). It is highly probable that similar effects also occur in the EMAC model system. Therefore, our decision on the preferred model setup for climatological simulations of the mineral dust cycle with EMAC is not dependent on the results of nudged simulations.

\subsection{May/June 2006: SAMUM}

During the Saharan Mineral Dust Experiment (SAMUM: Kandler et al., 2009; Knippertz et al., 2009) the mass concentrations of desert aerosols were measured near Tinfou $\left(30^{\circ} 14^{\prime} \mathrm{N}, 5^{\circ} 36^{\prime} \mathrm{W}, 684 \mathrm{~m}\right.$ a.s.l. $)$ in southern Morocco from 12 May to 6 June 2006. For this episode the period from 1 April to 30 June 2006 was simulated.

Figure 5 compares the simulated dust concentrations of the grid box containing the measurement site with the measured ones. The diameter of the largest emitted particles in TG is $15.88 \mu \mathrm{m}$. The simulated mean concentration is with $407 \mu \mathrm{g} \mathrm{m}^{-3} 37 \%$ higher than the $\mathrm{PM}_{10}$ measurements $\left(291 \mu \mathrm{g} \mathrm{m}^{-3}\right)$ and much lower than the TSP values $\left(9742 \mu \mathrm{g} \mathrm{m}^{-3}\right)$. In the measurements particles larger than $10 \mu \mathrm{m}$ in diameter account for more than $90 \%$ of the total airborne aerosol mass under high dust concentrations. Local wind speed observations indicate that large particles $(d>10 \mu \mathrm{m})$ were locally emitted, while a significant portion of the smaller ones stems from remote sources and was advected to the measurement site (Kandler et al., 2009). This explains the difference between measured and simulated concentrations, especially during the local strong-wind period from 23 to 27 May. Due to its coarse horizontal resolution of about $155 \mathrm{~km}$, EMAC is not able to produce strong local dust emission events that, e.g., result from canalisation effects of the regional orography. A second reason for the differences of the concentration values during this period is that TG does not take the super-coarse mode into account. However, this mode contributes most to the observed total aerosol mass, as described above. Overall, it is a satisfying result that the mean value of the simulated dust concentration over the whole time series is higher than the measured $\mathrm{PM}_{10}$ and much lower than the TSP concentration. 
Regional scale effects that are not captured by EMAC with the horizontal resolution T85 could lead to a time shift between measurements and the simulation. For instance, there is a measured maximum on 1 June while a peak in the simulation occurs on 2 June. Therefore, mean values for the six periods, named DP1, DP2, DP3, IP1, IP2, and "advection from SE", as described by Kandler et al. (2009) are considered, that are displayed in Fig. 5.

As described above, during DP1, IP1, and IP2 the simulated concentrations are higher than the $\mathrm{PM}_{10}$ and lower than the TSP measurements. The low-dust periods IP1 and IP2 illustrate desert background conditions that are represented well by EMAC. Without freshly emitted, large particles the TSP concentrations are only slightly above the simulated ones. DP2 is the local strong-wind period discussed earlier. The concentrations for the period "advection from SE" (Kandler et al., 2009) are underestimated by EMAC. This is due to relatively small discrepancies between the simulated and real flow patterns. At least the simulated concentration of soluble particles is one order of magnitude higher than the one of insoluble particles (not shown). This indicates that the dust has been advected to the measurement site because freshly emitted dust is assumed to be insoluble in the model. For DP3 the simulated concentrations are even higher than TSP. The periods "advection from SE" and DP3 are further investigated later in this section.

In contrast to those longer periods, two density currents were observed during SAMUM that generated high dust concentrations on 12 and 13 May (DC1) and on 31 May and 1 June (DC2) as discussed by Knippertz et al. (2007). DC1 is apparent in EMAC by a rapid increase of the simulated concentrations of insoluble particles in the night from 12 to 13 May. The measured TSP values are one order of magnitude higher because of the mobilisation of super-coarse particles that are not emitted in the model as mentioned above. The simulated concentrations are pretty low when DC2 was observed, but they increase rapidly somewhat later. Here again regional scale canalisation effects could be the reason for a delayed arrival of dusty air at Tinfou in the model.

This analysis points out the limitations of the global model concerning the regional and temporal resolution of smallscale processes causing massive dust emission. We also note that a comparison between a global simulation and measurements at one station is problematic. A more equitable approach to evaluate EMAC is to validate the results on a larger scale, which is done in the following.

Figure 6 compares EMAC with the MSG dust RGB composite at 12:00 UTC, 1 June 2006. EMAC simulates dust concentrations higher than $5000 \mu \mathrm{g} \mathrm{m}^{-3}$ on the lowest model layer in central Algeria. The forecast of the BSC/DREAM8b model for this time shows dust concentrations in the same order of magnitude in this region (not shown). The pinkish colours in the MSG composite corroborate a huge amount of airborne dust at the same place. Also in the southern part of
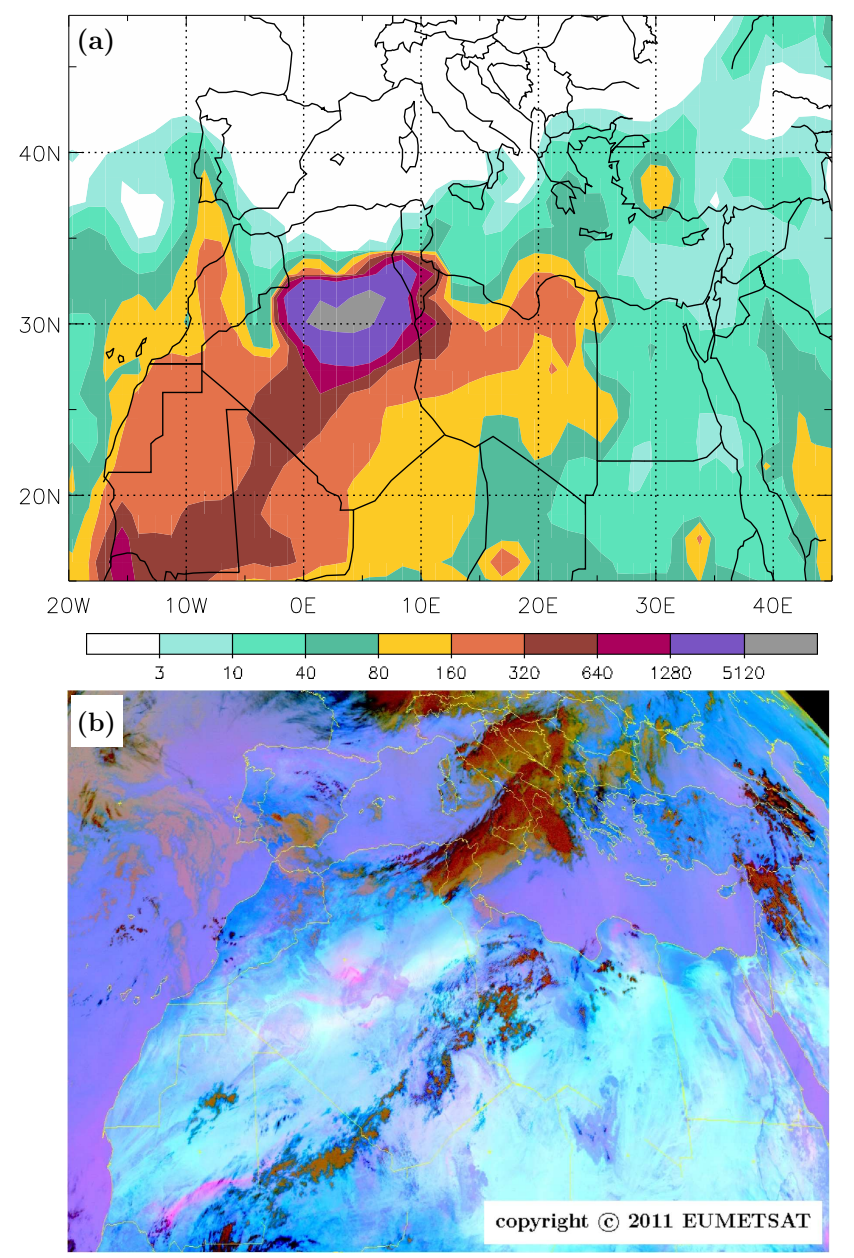

Fig. 6. Dust concentration $\left(\mu \mathrm{g} \mathrm{m}^{-3}\right)$ on the lowest model layer of EMAC (a) and MSG dust RGB composite (b) on 1 June 2006 12:00 UTC.

Mauritania there are indications for dust in the satellite image and high concentrations in the EMAC results.

On several other days during this episode the MSG dust composite shows dust aerosol in single regions over North Africa (not shown). There is high qualitative congruence between the EMAC results and the satellite composites at days with strong signals in the MSG images, e.g., on 11 May in South-Algeria and Niger, on 16 May in West-Algeria, on 22 May in West-Algeria, North-Mali and North Mauritania, on 24 and 25 May in West-Algeria and Mali, and on 29 May in West-Mali and South-East-Mauritania.

The period "advection from SE" on 21 and 22 May seemed not to be captured by the model on the first sight. However, on 21 and 22 May the model simulates high dust emissions in Mali and West-Algeria. This dust is transported northwards but not far enough to reach Tinfou. The comparison to MSG composites confirms that this event is reproduced quite well. Only a small displacement inhibits a better agreement with in situ measurements in this case. 

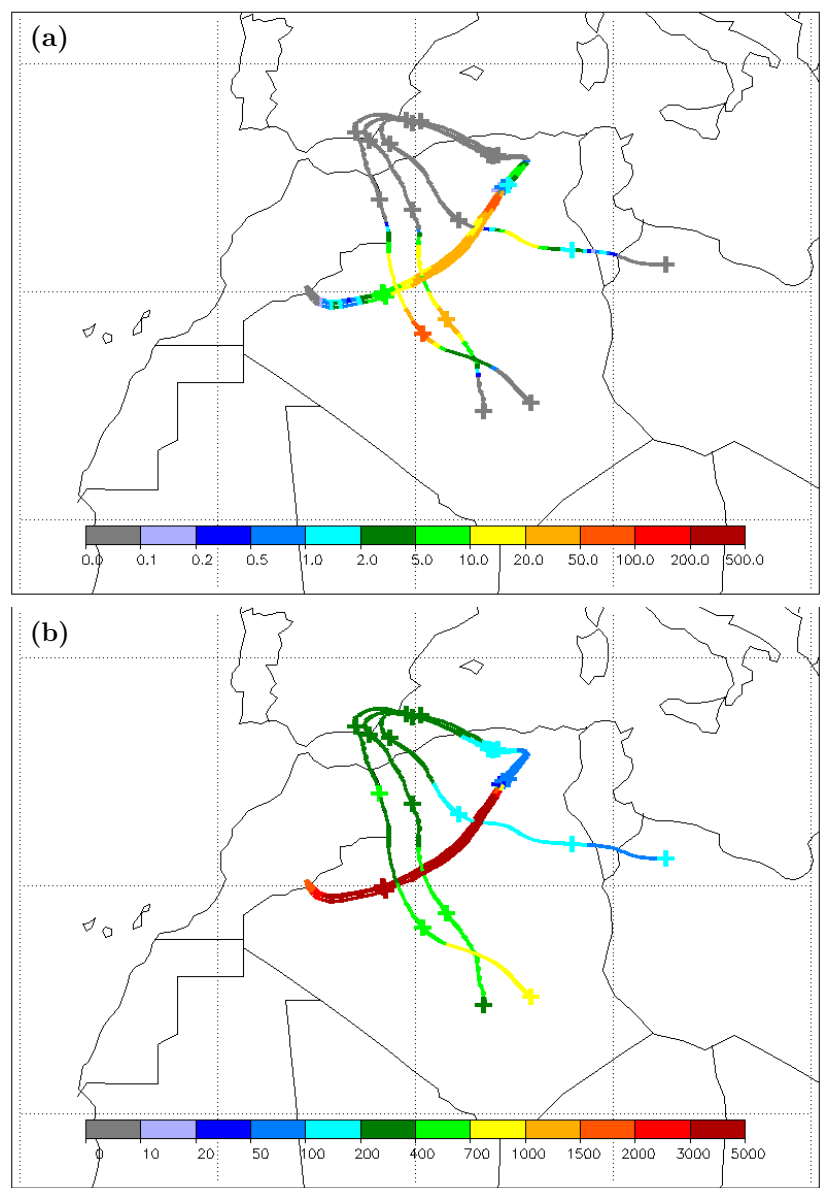

Fig. 7. Eight-day backward trajectories initialised on 3 June 2006 00:00 UTC starting from the three lowest model layers at Tinfou. A " + " is drawn every $24 \mathrm{~h}$. Coloured variables along the trajectories are (a) the dust emission ( $\mu \mathrm{g} \mathrm{m}^{-2} \mathrm{~s}^{-1}$ ) and (b) the dust concentration $\left(\mu \mathrm{g} \mathrm{m}^{-3}\right)$.

During DP3 EMAC produces a higher dust concentration than observed. Satellite images and the 2D-fields of the simulated dust concentrations show a dust front evolving in North-Algeria on 1 June that spreads south-westwards on the following days. The MSG composites indicate a good representation of the location of the dust front by the model. However, EMAC overestimates the dust emission along the front leading to higher concentrations at the measurement station than observed. From the model results no clear distinction can be made between DC2 and the advection of air with high dust concentrations from North-Algeria.

Further insight into this episode can be obtained by trajectory analyses. Trajectories were calculated from 5-hourly EMAC model output using the LAGRangian ANalysis TOol (LAGRANTO: Wernli and Davies, 1997). Various model variables, e.g., the dust concentration and the surface dust emission from the Eulerian model output are traced along the trajectories. Here the simulated and observed peak in the

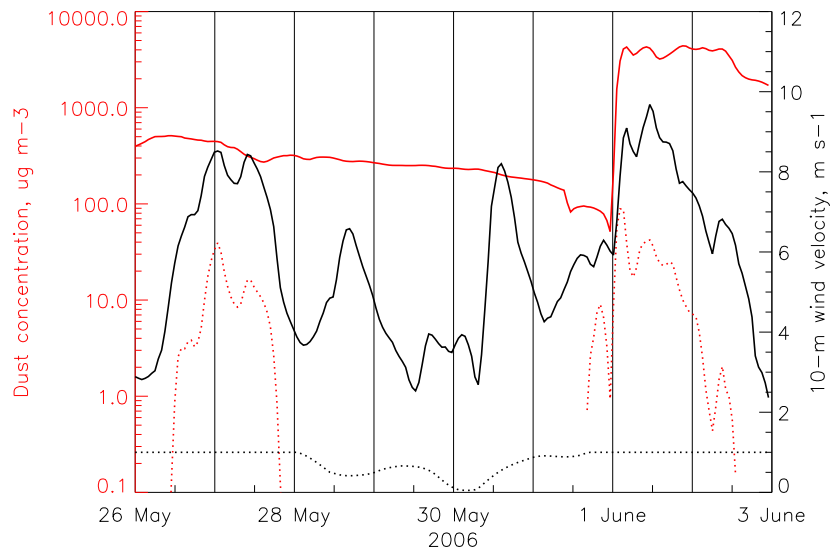

Fig. 8. Mean values along the trajectories. According to the left axis: dust concentration (solid red line, $\mu \mathrm{g} \mathrm{m}^{-3}$ ), dust emission (dotted red line, $\mu \mathrm{g} \mathrm{m}^{-2} \mathrm{~s}^{-1}$ ); according to the right axis: $10-\mathrm{m}$ wind velocity (solid black line, $\mathrm{ms}^{-1}$ ), Land-Sea-Mask (dotted black line).

dust concentrations at the SAMUM measurement site on 3 June is investigated. Eight-day backward trajectories starting from the three lowest model layers at the station show the simulated dust emission and concentration along the air parcel trajectories (Fig. 7). Strong emissions of more than $20 \mu \mathrm{g} \mathrm{m}^{-2} \mathrm{~s}^{-1}$ during 1 June (even 50-100 $\mathrm{g} \mathrm{m}^{-2} \mathrm{~s}^{-1}$ in the first hours of the day) lead to a rapid increase in the dust concentrations along the trajectories. The heavy emissions can also be seen in the MSG dust composite at 12:00 UTC 1 June (Fig. 6b). This reveals that the dust reaching Tinfou on 3 June was emitted on 1 June over the southern slope of the Atlas Mountains in Algeria.

Figure 8 shows the mean values of several variables along the trajectories. The very abrupt acceleration of the $10-\mathrm{m}$ wind speed during the first hours of 1 June from 6 to $9 \mathrm{~m} \mathrm{~s}^{-1}$ causes strong dust emissions of about $100 \mu \mathrm{g} \mathrm{m}^{-2} \mathrm{~s}^{-1}$ which again leads to an abrupt increase of the dust concentration from less than 100 to more than $4000 \mu \mathrm{g} \mathrm{m}^{-3}$. While the 10-m wind velocity and the emissions decrease during the following two days, the concentration stays on a high level. When the air reaches the measurement site on 3 June 00:00 UTC a value of about $1700 \mu \mathrm{g} \mathrm{m}^{-3}$ is simulated.

Figure 8 shows high 10-m wind speeds also on 27, 28, and 30 May. The maximum on 27 May is associated with high dust emissions in central Algeria (see also Fig. 7). However, during this time the altitude of the trajectories is too high for the air parcels to be direcly affected by these emissions. Therefore, the freshly emitted dust does not reach the trajectories and the dust concentration does not increase. The two peaks in the wind speed on 28 and 30 May occur when the trajectories cross the Mediterranean, where dust emission is impossible. 


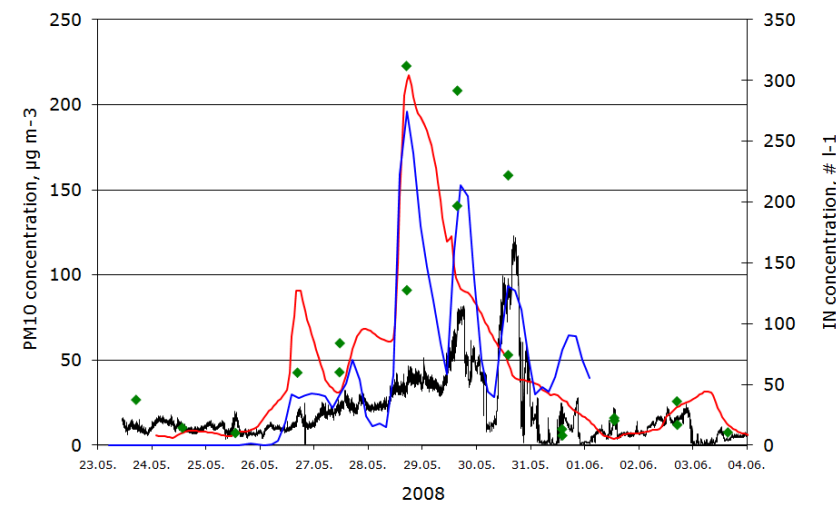

Fig. 9. According to the left axis: time series of the measured $\mathrm{PM}_{10}$ concentration (black line, $\mu \mathrm{g} \mathrm{m}^{-3}$ ) at Mt. Kleiner Feldberg, Germany and the simulated dust concentrations at Mt. Kleiner Feldberg of EMAC (red line) and BSC/DREAM8b (blue line). According to the right axis: measured number concentration ice nuclei (green diamonds, number per litre $\left.\left[\# 1^{-1}\right]\right)$. Measurements are described in Klein et al. (2010).

\subsection{May/June 2008: Mt. Kleiner Feldberg}

At the Taunus Observatory of the Goethe-University of Frankfurt/Main on Mt. Kleiner Feldberg in Germany $\left(50^{\circ} 13^{\prime} \mathrm{N}, 8^{\circ} 27^{\prime} \mathrm{E}, 825 \mathrm{~m}\right.$ a.s.l. $)$ the number concentration of ice nuclei (IN) and $\mathrm{PM}_{10}$ concentrations have been measured since April 2008 (Klein et al., 2010). Here, a Sahara dust episode observed in May 2008 is considered. The EMAC simulation was performed from 1 April to 30 June 2008.

The measured concentrations of $\mathrm{PM}_{10}$ and IN, the simulated dust concentrations of BSC/DREAM8b, and the concentrations of the grid box containing the measurement site simulated by EMAC show peaks at the end of May 2008 (Fig. 9). The mean values from 24 May to 1 June are highest in the EMAC simulation with $54.84 \mu \mathrm{g} \mathrm{m}^{-3}$, followed by BSC/DREAM8b with $43.38 \mu \mathrm{g} \mathrm{m}^{-3}$ and the $\mathrm{PM}_{10}$ measurements with $23.91 \mu \mathrm{g} \mathrm{m}^{-3}$. This is a reasonable result because the maximum diameter of particles in EMAC is $15.88 \mu \mathrm{m}$ (see Sect. 4.1) while it is $12 \mu \mathrm{m}$ in the BSC/DREAM8b data and, self-evident, $10 \mu \mathrm{m}$ in the $\mathrm{PM}_{10}$ measurements.

The absolute maximum is simulated at the same time by EMAC and BSC/DREAM8b, i.e., in the afternoon hours of 28 May. It reaches values of $218 \mu \mathrm{g} \mathrm{m}^{-3}$ in EMAC and $196 \mu \mathrm{g} \mathrm{m}^{-3}$ in the BSC/DREAM8b simulation. The $\mathrm{PM}_{10}$ measurements show no distinct peak at this time, but one and two days later, when the simulated values decrease again. BSC/DREAM8b reproduces the observed peaks on 29 and 30 May, while the decline in EMAC is almost monotonously. Klein et al. (2010) assumed that the deviations on 28 and 29 May can be traced back to thunderstorm development over the Taunus hills that is not represented in BSC/DREAM8b and EMAC because it is a sub-grid scale phenomenon. This could explain the much higher congruence between the two
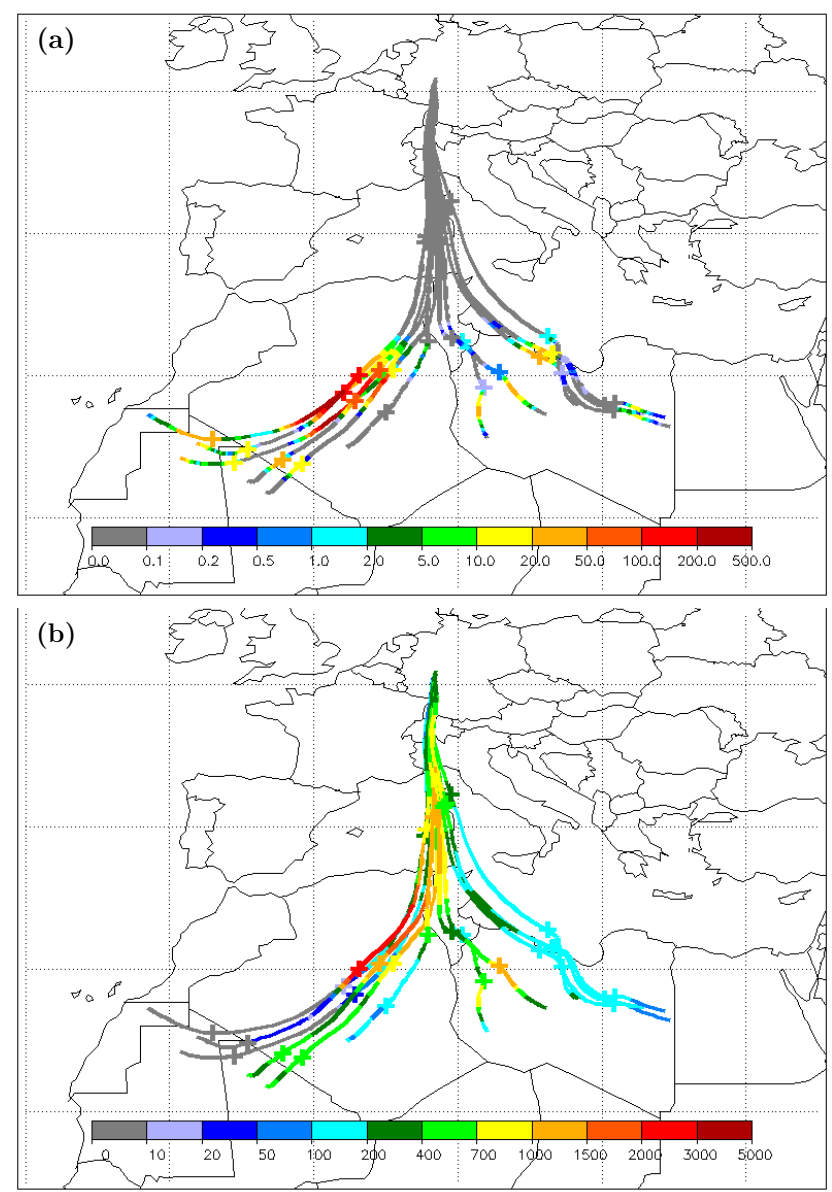

Fig. 10. 90-h backward trajectories initialised on 28 May 2008 18:00 UTC starting in intervals of $30 \mathrm{hPa}$ from the surface to $350 \mathrm{hPa}$ at Mt. Kleiner Feldberg. Only trajectories with northward displacement larger than $22^{\circ}$ latitude are displayed. Coloured variables along the trajectories are (a) the dust emission $\left(\mu \mathrm{g} \mathrm{m}^{-2} \mathrm{~s}^{-1}\right)$ and (b) the dust concentration $\left(\mu \mathrm{g} \mathrm{m}^{-3}\right)$. A “+” is drawn every $24 \mathrm{~h}$.

simulations compared to the one between the simulations and the $\mathrm{PM}_{10}$ measurements. Another effect, that might reduce the comparability of these time series, is the fact that many other species like soot, acids, and sea salt contribute to the $\mathrm{PM}_{10}$ measurements (Klein et al., 2010).

The correlation is higher between the simulated dust concentrations and the measured IN concentrations. Mineral dust particles act very efficiently as heterogeneous ice nuclei (Zuberi et al., 2002; DeMott et al., 2003a,b; Cziczo et al., 2004; Richardson et al., 2007). Linear regression of IN number concentration against simulated dust concentration yields correlation coefficients $R_{\text {DREAM }}=0.888$ and $R_{\text {EMAC }}=0.729$ for the BSC/DREAM $8 \mathrm{~b}$ and the EMAC simulation, respectively.

As before, for this episode the source region of the dust that reaches Central Europe can be identified by backward trajectories. Very strong dust emissions in Central Algeria 
of more than $200 \mu \mathrm{g} \mathrm{m}^{-2} \mathrm{~s}^{-1}$ on 26 May (Fig. 10a) lead to high dust concentrations along the trajectories. The concentrations decrease from more than $2000 \mu \mathrm{g} \mathrm{m}^{-3}$ on 26 May to values of about $200 \mu \mathrm{g} \mathrm{m}^{-3}$ when the trajectories reach Mt. Kleiner Feldberg (Fig. 10b). Klein et al. (2010) showed backward trajectories calculated by the German Meteorological Service confirming the advection of air from the Sahara to Central Europe. The EMAC results reveal that most of the dust was emitted in the afternoon of 26 May in the north-eastern part of the province Adrar in central Algeria (Fig. 10a).

In terms of source region and the direct transport pattern across the western Mediterranean, this event is comparable to the one studied by Sodemann et al. (2006) in October 2000.

\section{Summary and conclusions}

This study investigates the mineral dust cycle in the GCCM EMAC. In order to determine the model setup that simulates the most reasonable mineral dust cycle, sensitivity studies were conducted with regard to the chemistry setup, the horizontal model resolution, and the dust emission scheme.

Freshly emitted dust particles are assumed to be insoluble. By coating of sulphate they become soluble and are scavenged out of the atmosphere much more efficiently. Therefore, a basic sulphur chemistry is required to avoid an unrealistic, almost homogeneous distribution of the dust over the entire globe.

Results of five-year time slice simulations show in parts severe differences between the four considered horizontal resolutions (T42, T63, T85, and T106) and the two implemented dust emission schemes (by Balkanski et al., 2004 and by Tegen et al., 2002). While the seasonality of the emission and the transatlantic transport of dust from North Africa is well reproduced in all simulations, the accentuation of the Bodéle Depression is not captured with the T42 and the T63BK setups. With the resolutions T42 and T63 there are some grid points at the northern slope of the Himalayas where on the one hand, high 10-m wind velocities are simulated because of high elevation, and on the other hand, these grid points belong to the Tarim Basin, which is a dust source region. Hence, T42 and T63 overestimate the dust emissions in this region, especially during summer, leading to an erroneous annual cycle of Central Asian dust activity. The northward transport of this dust causes unrealistically high dust loads in the Arctic. With the resolutions T85 and T106 the elevated grid points and those in the basin can be distinguished leading to much lower emissions in the Tarim Basin and a more realistic dust burden in polar regions. This behaviour is independent of the dust emission scheme.

Independent of the model resolution the BK scheme produces too strong emissions in the Thar Desert in North-WestIndia. On average the emissions are 2.4 times higher in India than in the Sahara, which is in contradiction to current scientific knowledge, considering the Sahara Desert to be the world's largest dust source. The annual cycle of the dust load over the Indian subcontinent is reproduced correctly only with T106BK and in the simulations with the TG scheme.

Finally, due to the better performance in the comparison to AEROCOM and in situ measurements of dust deposition and surface concentration, the T85TG setup is found to generate a more realistic global dust cycle than the T106TG simulation. T85TG is also able to fairly accurately simulate single dust episodes. The large scale flow patterns are reproduced and the TG scheme generates dust emissions that lead to dust concentrations in the same order of magnitude as observed. Especially the transport pathways of dust are simulated realistically according to MSG images and results of the BSC/DREAM8b regional model. Nevertheless, the investigation of episodes points to the limitations of the GCCM EMAC, when it comes to resolving effects on small spacial and temporal scales that cannot be represented by a GCCM. In addition, trajectory analyses allowed for a detailed investigation of the dust transport and of the processes that occur along the pathway. For both episodes the source regions of the dust, reaching the measurement sites, could be identified.

A model setup with the horizontal resolution of T85, including a basic sulphur chemistry and using the dust emission scheme by Tegen et al. (2002) is recommended for future investigations of the mineral dust cycle with the EMAC GCCM.

\section{Supplement related to this article is available online at: http://www.atmos-chem-phys.net/12/1611/2012/ acp-12-1611-2012-supplement.zip.}

Acknowledgements. This work was funded by the Earth System Research Centre Geocycles at the University of Mainz. We thank Rolf Sander for developing the chemistry setup and Patrick Jöckel for providing data and the introduction to EMAC. We are grateful to the anonymous referees for their constructive criticism, to Peter Knippertz for helpful discussions and we would like to thank Konrad Kandler for providing data of the SAMUM field campaign and Holger Klein for supplying data from Mt. Kleiner Feldberg. We thank Ina Tegen for providing the code and input fields for the TG scheme and the useful discussion about it. We used images from the BSC/DREAM8b model, operated by the Barcelona Supercomputing Center (http://www.bsc.es/projects/earthscience/DREAM/) and from the EUMETSAT MSG $0^{\circ}$ satellite. The simulations were performed at the German Climate Computing Center (DKRZ) in Hamburg.

Edited by: A. J. G. Baumgaertner 


\section{References}

Balkanski, Y., Schulz, M., Claquin, T., Moulin, C., and Ginoux, P.: Emission of Atmospheric Trace Compounds, chap. Global Emissions of Mineral Aerosol: Formulation and Validation using satellite Imagery, 239-267, Kluwer, 2004.

Bian, H., Chin, M., Rodriguez, J. M., Yu, H., Penner, J. E., and Strahan, S.: Sensitivity of aerosol optical thickness and aerosol direct radiative effect to relative humidity, Atmos. Chem. Phys., 9, 2375-2386, doi:10.5194/acp-9-2375-2009, 2009.

Chadwick, O. A., Derry, L. A., Vitousek, P. M., Huebert, B. J., and Hedin, L. O.: Changing sources of nutrients during four million years of ecosystem development, Nature, 397, 491-497, 1999.

Chen, Y. S., Sheen, P. C., Chen, E. R., Liu, Y. K., Wu, T. N., and Yang, C. Y.: Effects of Asian dust storm events on daily mortality in Taipei, Taiwan, Environ. Res., 95, 151-155, doi:10.1016/j.envres.2003.08.008, 2004.

Cheng, T., Peng, Y., Feichter, J., and Tegen, I.: An improvement on the dust emission scheme in the global aerosol-climate model ECHAM5-HAM, Atmos. Chem. Phys., 8, 1105-1117, doi:10.5194/acp-8-1105-2008, 2008.

Cziczo, D. J., Murphy, D. M., Hudson, P. K., and Thomson, D. S.: Single particle measurements of the chemical composition of cirrus ice residue during CRYSTAL-FACE, J. Geophys. Res.Atmos., 109, D04201, doi:10.1029/2003JD004032, 2004.

DeMott, P. J., Cziczo, D. J., Prenni, A. J., Murphy, D. M., Kreidenweis, S. M., Thomson, D. S., Borys, R., and Rogers, D. C.: Measurements of the concentration and composition of nuclei for cirrus formation, Proc. Natl. Acad. Sci. USA, 100, 14655-14660, doi:10.1073/pnas.2532677100, 2003a.

DeMott, P. J., Sassen, K., Poellot, M. R., Baumgardner, D., Rogers, D. C., Brooks, S. D., Prenni, A. J., and Kreidenweis, S. M.: African dust aerosols as atmospheric ice nuclei, Geophys. Res. Lett., 30, 1732, doi:10.1029/2003GL017410, 2003 b.

Fécan, F., Marticorena, B., and Bergametti, G.: Parametrization of the increase of the aeolian erosion threshold wind friction velocity due to soil moisture for arid and semi-arid areas, Ann. Geophys., 17, 149-157, doi:10.1007/s00585-999-0149-7, 1999.

Geng, H., Park, Y., Hwang, H., Kang, S., and Ro, C. U.: Elevated nitrogen-containing particles observed in Asian dust aerosol samples collected at the marine boundary layer of the Bohai Sea and the Yellow Sea, Atmos. Chem. Phys., 9, 6933-6947, doi:10.5194/acp-9-6933-2009, 2009.

Ginoux, P., Chin, M., Tegen, I., Prospero, J., Holben, B., Dubovik, O., and Lin, S. J.: Sources and distributions of dust aerosols simulated with the GOCART model, J. Geophys. Res.-Atmos., 106, 20255-20273, 2001.

Ginoux, P., Prospero, J. M., Torres, O., and Chin, M.: Long-term simulation of global dust distribution with the GOCART model: correlation with North Atlantic Oscillation, Environ. Modell. Softw., 19, 113-128, doi:10.1016/S1364-8152(03)00114-2, 2004.

Habib, G., Venkataraman, C., Chiapello, I., Ramachandran, S., Boucher, O., and Reddy, M. S.: Seasonal and interannual variability in absorbing aerosols over India derived from TOMS: Relationship to regional meteorology and emissions, Atmos. Environ., 40, 1909-1921, doi:10.1016/j.atmosenv.2005.07.077, 2006.

Haywood, J. M., Francis, P. N., Glew, M. D., and Taylor, J. P.: Optical properties and direct radiative effect of Saharan dust: A case study of two Saharan dust outbreaks using aircraft data, J.
Geophys. Res.-Atmos., 106, 18417-18430, 2001.

Heintzenberg, J.: The SAMUM-1 experiment over Southern Morocco: overview and introduction, Tellus Ser. B-Chem. Phys. Meteorol., 61, 2-11, doi:10.1111/j.1600-0889.2008.00403.x, 2009.

Huneeus, N., Schulz, M., Balkanski, Y., Griesfeller, J., Prospero, J., Kinne, S., Bauer, S., Boucher, O., Chin, M., Dentener, F., Diehl, T., Easter, R., Fillmore, D., Ghan, S., Ginoux, P., Grini, A., Horowitz, L., Koch, D., Krol, M. C., Landing, W., Liu, X., Mahowald, N., Miller, R., Morcrette, J. J., Myhre, G., Penner, J., Perlwitz, J., Stier, P., Takemura, T., and Zender, C. S.: Global dust model intercomparison in AeroCom phase I, Atmos. Chem. Phys., 11, 7781-7816, doi:10.5194/acp-11-7781-2011, 2011.

IPCC: Climate Change 2007: The Physical Science Basis. Contribution of Working Group I to the Fourth Assessment Report of the Intergovernmental Panel on Climate Change, edited by: Solomon, S., Qin, D., Manning, M., Chen, Z., Marquis, M., Averyt, K. B., Tignor, M. and Miller, H. L., Cambridge University Press, Cambridge, UK and New York, NY, USA, 2007.

Janjic, Z. I.: The Step-Mountain Eta Coordinate Model: Further Developments of the Convection, Viscous Sublayer, and Turbulence Closure Schemes, Mon. Weather Rev., 122, 927-945, 1994.

Jöckel, P., Sander, R., Kerkweg, A., Tost, H., and Lelieveld, J.: Technical note: The Modular Earth Submodel System (MESSy) - a new approach towards Earth System Modeling, Atmos. Chem. Phys., 5, 433-444, doi:10.5194/acp-5-433-2005, 2005.

Jöckel, P., Tost, H., Pozzer, A., Bruehl, C., Buchholz, J., Ganzeveld, L., Hoor, P., Kerkweg, A., Lawrence, M. G., Sander, R., Steil, B., Stiller, G., Tanarhte, M., Taraborrelli, D., Van Aardenne, J., and Lelieveld, J.: The atmospheric chemistry general circulation model ECHAM5/MESSy1: consistent simulation of ozone from the surface to the mesosphere, Atmos. Chem. Phys., 6, 50675104, doi:10.5194/acp-6-5067-2006, 2006.

Jöckel, P., Kerkweg, A., Pozzer, A., Sander, R., Tost, H., Riede, H., Baumgaertner, A., Gromov, S., and Kern, B.: Development cycle 2 of the Modular Earth Submodel System (MESSy2), Geosci. Model Dev., 3, 717-752, doi:10.5194/gmd-3-717-2010, 2010.

Jung, T., Gulev, S. K., Rudeva, I., and Soloviov, V.: Sensitivity of extratropical cyclone characteristics to horizontal resolution in the ECMWF model, Q. J. Roy. Meteor. Soc., 132, 1839-1857, doi:10.1256/qj.05.212, 2006.

Kandler, K., Schuetz, L., Deutscher, C., Ebert, M., Hofmann, H., Jaeckel, S., Jaenicke, R., Knippertz, P., Lieke, K., Massling, A., Petzold, A., Schladitz, A., Weinzierl, B., Wiedensohler, A., Zorn, S., and Weinbruch, S.: Size distribution, mass concentration, chemical and mineralogical composition and derived optical parameters of the boundary layer aerosol at Tinfou, Morocco, during SAMUM 2006, Tellus Ser. B-Chem. Phys. Meteorol., 61, 32-50, doi:10.1111/j.1600-0889.2008.00385.x, 2009.

Kang, J.-Y., Yoon, S.-C., Shao, Y., and Kim, S.-W.: Comparison of vertical dust flux by implementing three dust emission schemes in WRF/Chem, J. Geophys. Res.-Atmos., 116, D09202, doi:10.1029/2010JD014649, 2011.

Kerkweg, A., Buchholz, J., Ganzeveld, L., Pozzer, A., Tost, H., and Joeckel, P.: Technical note: An implementation of the dry removal processes DRY DEPosition and SEDImentation in the modular earth submodel system (MESSy), Atmos. Chem. Phys., 6, 4617-4632, doi:10.5194/acp-6-4617-2006, 2006a.

Kerkweg, A., Sander, R., Tost, H., and Joeckel, P.: Technical 
note: Implementation of prescribed (OFFLEM), calculated (ONLEM), and pseudo-emissions (TNUDGE) of chemical species in the Modular Earth Submodel System (MESSy), Atmos. Chem. Phys., 6, 3603-3609, doi:10.5194/acp-6-3603-2006, 2006b.

Kerkweg, A., Joeckel, P., Pozzer, A., Tost, H., Sander, R., Schulz, M., Stier, P., Vignati, E., Wilson, J., and Lelieveld, J.: Consistent simulation of bromine chemistry from the marine boundary layer to the stratosphere - Part 1: Model description, sea salt aerosols and pH, Atmos. Chem. Phys., 8, 5899-5917, doi:10.5194/acp-85899-2008, 2008.

Klein, H., Nickovic, S., Haunold, W., Bundke, U., Nillius, B., Ebert, M., Weinbruch, S., Schuetz, L., Levin, Z., Barrie, L. A., and Bingemer, H.: Saharan dust and ice nuclei over Central Europe, Atmos. Chem. Phys., 10, 10211-10221, doi:10.5194/acp10-10211-2010, 2010.

Knippertz, P., Deutscher, C., Kandler, K., Mueller, T., Schulz, O., and Schuetz, L.: Dust mobilization due to density currents in the Atlas region: Observations from the Saharan Mineral Dust Experiment 2006 field campaign, J. Geophys. Res.-Atmos., 112, D21109, doi:10.1029/2007JD008774, 2007.

Knippertz, P., Ansmann, A., Althausen, D., Mueller, D., Tesche, M., Bierwirth, E., Dinter, T., Mueller, T., Von Hoyningen-Huene, W., Schepanski, K., Wendisch, M., Heinold, B., Kandler, K., Petzold, A., Schuetz, L., and Tegen, I.: Dust mobilization and transport in the northern Sahara during SAMUM 2006 - a meteorological overview, Tellus Ser. B-Chem. Phys. Meteorol., 61, 12-31, doi:10.1111/j.1600-0889.2008.00380.x, 2009.

Kwon, H. J., Cho, S. H., Chun, Y., Lagarde, F., and Pershagen, G.: Effects of the Asian dust events on daily mortality in Seoul, Korea, Environ. Res., 90, 1-5, doi:10.1006/enrs.2002.4377, 2002.

Lee, Y. H., Chen, K., and Adams, P. J.: Development of a global model of mineral dust aerosol microphysics, Atmos. Chem. Phys., 9, 2441-2458, doi:10.5194/acp-9-2441-2009, 2009.

Mahowald, N. M., Engelstaedter, S., Luo, C., Sealy, A., Artaxo, P., Benitez-Nelson, C., Bonnet, S., Chen, Y., Chuang, P. Y., Cohen, D. D., Dulac, F., Herut, B., Johansen, A. M., Kubilay, N., Losno, R., Maenhaut, W., Paytan, A., Prospero, J. A., Shank, L. M., and Siefert, R. L.: Atmospheric Iron Deposition: Global Distribution, Variability, and Human Perturbations, Annu. Rev. Mar. Sci., 1, 245-278, doi:10.1146/annurev.marine.010908.163727, 2009.

Marti, O., Braconnot, P., Dufresne, J. L., Bellier, J., Benshila, R., Bony, S., Brockmann, P., Cadule, P., Caubel, A., Codron, F., de Noblet, N., Denvil, S., Fairhead, L., Fichefet, T., Foujols, M. A., Friedlingstein, P., Goosse, H., Grandpeix, J. Y., Guilyardi, E., Hourdin, F., Idelkadi, A., Kageyama, M., Krinner, G., Levy, C., Madec, G., Mignot, J., Musat, I., Swingedouw, D., and Talandier, C.: Key features of the IPSL ocean atmosphere model and its sensitivity to atmospheric resolution, Clim. Dynam., 34, 1-26, doi:10.1007/s00382-009-0640-6, 2010.

Marticorena, B. and Bergametti, G.: Modeling the Atmospheric Dust Cycle .1. Design of A Soil-derived Dust Emission Scheme, J. Geophys. Res.-Atmos., 100, 16415-16430, doi:10.1029/95JD00690, 1995.

Martin, J. H. and Fitzwater, S. E.: Iron deficiency limits phytoplankton growth in the north-east Pacific subarctic, Nature, 331, 341-343, 1988.

Nickovic, S., Kallos, G., Papadopoulos, A., and Kakaliagou, O.: A model for prediction of desert dust cycle in the atmosphere, J. Geophys. Res.-Atmos., 106, 18113-18129, 2001.
Pérez, C., Nickovic, S., Baldasano, J. M., Sicard, M., Rocadenbosch, F., and Cachorro, V. E.: A long Saharan dust event over the western Mediterranean: Lidar, Sun photometer observations, and regional dust modeling, J. Geophys. Res.-Atmos., 111, D15214, doi:10.1029/2005JD006579, 2006 a.

Pérez, C., Nickovic, S., Pejanovic, G., Baldasano, J. M., and Oezsoy, E.: Interactive dust-radiation modeling: A step to improve weather forecasts, J. Geophys. Res.-Atmos., 111, D16206, doi:10.1029/2005JD006717, 2006b.

Prospero, J. M., Ginoux, P., Torres, O., Nicholson, S. E., and Gill, T. E.: Environmental characterization of global sources of atmospheric soil dust identified with the Nimbus 7 Total Ozone Mapping Spectrometer (TOMS) absorbing aerosol product, Rev. Geophys., 40, 1002, doi:10.1029/2000RG000095, 2002.

Remer, L. A., Kaufman, Y. J., Tanre, D., Mattoo, S., Chu, D. A., Martins, J. V., Li, R. R., Ichoku, C., Levy, R. C., Kleidman, R. G., Eck, T. F., Vermote, E., and Holben, B. N.: The MODIS aerosol algorithm, products, and validation, J. Atmos. Sci., 62, 947-973, doi:10.1175/JAS3385.1, 2005.

Richardson, M. S., DeMott, P. J., Kreidenweis, S. M., Cziczo, D. J., Dunlea, E. J., Jimenez, J. L., Thomson, D. S., Ashbaugh, L. L., Borys, R. D., Westphal, D. L., Casuccio, G. S., and Lersch, T. L.: Measurements of heterogeneous ice nuclei in the western United States in springtime and their relation to aerosol characteristics, J. Geophys. Res.-Atmos., 112, D02209, doi:10.1029/2006JD007500, 2007.

Röckner, E., Brokopf, R., Esch, M., Giorgetta, M., Hagemann, S., Kornblueh, L., Manzini, E., Schlese, U., and Schulzweida, U.: Sensitivity of simulated climate to horizontal and vertical resolution in the ECHAM5 atmosphere model, J. Clim., 19, 37713791, 2006.

Sander, R., Baumgaertner, A., Gromov, S., Harder, H., Joeckel, P., Kerkweg, A., Kubistin, D., Regelin, E., Riede, H., Sandu, A., Taraborrelli, D., Tost, H., and Xie, Z.: The atmospheric chemistry box model CAABA/MECCA-3.0, Geosci. Model Dev., 4, 373-380, doi:10.5194/gmd-4-373-2011, 2011.

Sassen, K., DeMott, P. J., Prospero, J. M., and Poellot, M. R.: Saharan dust storms and indirect aerosol effects on clouds: CRYSTAL-FACE results, Geophys. Res. Lett., 30, 1633, doi:10.1029/2003GL017371, 2003.

Shao, Y. and Raupach, M. R.: Effect of saltation bombardment on the entrainment of dust by wind, J. Geophys. Res.-Atmos., 98, 12719-12726, 1993.

Sodemann, H., Palmer, A. S., Schwierz, C., Schwikowski, M., and Wernli, H.: The transport history of two Saharan dust events archived in an Alpine ice core, Atmos. Chem. Phys., 6, 667-688, doi:10.5194/acp-6-667-2006, 2006.

Stier, P., Feichter, J., Kinne, S., Kloster, S., Vignati, E., Wilson, J., Ganzeveld, L., Tegen, I., Werner, M., Balkanski, Y., Schulz, M., Boucher, O., Minikin, A., and Petzold, A.: The aerosolclimate model ECHAM5-HAM, Atmos. Chem. Phys., 5, 11251156, doi:10.5194/acp-5-1125-2005, 2005.

Swap, R., Garstang, M., Greco, S., Talbot, R., and Kallberg, P.: Saharan dust in the Amazon Basin, Tellus Ser. B-Chem. Phys. Meteorol., 44, 133-149, 1992.

Tegen, I., Harrison, S. P., Kohfeld, K., Prentice, I. C., Coe, M., and Heimann, M.: Impact of vegetation and preferential source areas on global dust aerosol: Results from a model study, J. Geophys. Res.-Atmos., 107, 4576, doi:10.1029/2001JD000963, 2002. 
Textor, C., Schulz, M., Guibert, S., Kinne, S., Balkanski, Y., Bauer, S., Berntsen, T., Berglen, T., Boucher, O., Chin, M., Dentener, F., Diehl, T., Easter, R., Feichter, H., Fillmore, D., Ghan, S., Ginoux, P., Gong, S., Kristjansson, J. E., Krol, M., Lauer, A., Lamarque, J. F., Liu, X., Montanaro, V., Myhre, G., Penner, J., Pitari, G., Reddy, S., Seland, O., Stier, P., Takemura, T., and Tie, X.: Analysis and quantification of the diversities of aerosol life cycles within AeroCom, Atmos. Chem. Phys., 6, 1777-1813, doi:10.5194/acp-6-1777-2006, 2006.

Timmreck, C. and Schulz, M.: Significant dust simulation differences in nudged and climatological operation mode of the AGCM ECHAM, J. Geophys. Res.-Atmos., 109, D13202, doi:10.1029/2003JD004381, 2004.

Tost, H., Joeckel, P., Kerkweg, A., Sander, R., and Lelieveld, J.: Technical note: A new comprehensive SCAVenging submodel for global atmospheric chemistry modelling, Atmos. Chem. Phys., 6, 565-574, doi:10.5194/acp-6-565-2006, 2006.
Vignati, E., Wilson, J., and Stier, P.: M7: An efficient sizeresolved aerosol microphysics module for large-scale aerosol transport models, J. Geophys. Res.-Atmos., 109, D22202, doi:10.1029/2003JD004485, 2004.

Washington, R., Todd, M., Middleton, N. J., and Goudie, A. S.: Dust-storm source areas determined by the total ozone monitoring spectrometer and surface observations, Ann. Assoc. Am. Geogr., 93, 297-313, 2003.

Wernli, H. and Davies, H. C.: A Lagrangian-based analysis of extratropical cyclones .1. The method and some applications, Q. J. Roy. Meteor. Soc., 123, 467-489, 1997.

Zuberi, B., Bertram, A. K., Cassa, C. A., Molina, L. T., and Molina, M.: Heterogeneous nucleation of ice in $\left(\mathrm{NH}_{4}\right)(2) \mathrm{SO}_{4}-\mathrm{H}_{2} \mathrm{O}$ particles with mineral dust immersions, Geophys. Res. Lett., 29, 1504, doi:10.1029/2001GL014289, 2002. 